\title{
Money Creation and the Shadow Banking System
}

\section{Citation}

Sunderam, Adi. "Money Creation and the Shadow Banking System." Review of Financial Studies 28, no. 4 (April 2015): 939-977.

\section{Published Version}

http://rfs.oxfordjournals.org/content/early/2014/11/12/rfs.hhu083

\section{Permanent link}

http://nrs.harvard.edu/urn-3:HUL.InstRepos:27336543

\section{Terms of Use}

This article was downloaded from Harvard University's DASH repository, and is made available under the terms and conditions applicable to Open Access Policy Articles, as set forth at http:// nrs.harvard.edu/urn-3:HUL.InstRepos:dash.current.terms-of-use\#OAP

\section{Share Your Story}

The Harvard community has made this article openly available.

Please share how this access benefits you. Submit a story.

\section{Accessibility}




\title{
Money Creation and the Shadow Banking System*
}

\author{
Adi Sunderam
}

Harvard Business School and NBER

September 2014

*Corresponding author: Adi Sunderam, Baker Library 359, Harvard Business School, Boston, MA 02163; email: asunderam@hbs.edu; phone: 617-495-6644. I thank three anonymous referees, Tobias Adrian, Geert Bekaert (the editor), Seth Carpenter, Adam Copeland, Sergey Chernenko, Doug Diamond, Darrell Duffie, Andrea Eisfeldt, Vincent Glode, Gary Gorton, Robin Greenwood, Sam Hanson, Zhiguo He, Arvind Krishnamurthy, Andrew Metrick, Lasse Pedersen, Morgan Ricks, David Romer, David Scharfstein, Andrei Shleifer, Kelly Shue, Jeremy Stein, Gustavo Suarez, Annette Vissing-Jorgensen, and seminar participants at Chicago Booth, the Federal Reserve Board Shadow Banking workshop, FRIC 2013, HEC Paris, Johns Hopkins, the NBER Macroeconomics and Finance Summer Institute, the New York Fed, Rochester, and UCLA for helpful comments and suggestions. Brian Chen provided excellent research assistance. 


\begin{abstract}
It is widely argued that shadow banking grew rapidly before the recent financial crisis because of rising demand for "money-like" claims. This paper assesses a key premise of this argument: that investors actually treated short-term debt issued by shadow banks as a money-like claim. I present a model where the financial sector and the central bank jointly respond to demand for money-like claims. The model generates predictions about the prices and quantities of Treasury bills, central bank reserves, and shadow bank debt. These predictions are borne out in the data, suggesting investors did treat shadow bank debt as money-like.
\end{abstract}


A key function of financial intermediaries is to provide savers with "money-like" claims (Diamond and Dybvig, 1983; Gorton and Pennacchi, 1990). Indeed, many argue that securitization grew rapidly before the recent financial crisis precisely because it was a financial innovation that enabled intermediaries to supply more money-like claims (e.g., Gorton and Metrick, 2010a,b, 2011; Krishnamurthy and Vissing-Jorgensen, 2013). In this narrative, the so-called "shadow banking system" used highly-rated, long-term securitized bonds as collateral to back the issuance of money-like, short-term claims. These claims, while not used directly in transactions, had the short-term safety and liquidity needed to function as stores of value, and thus serve as imperfect substitutes for money. In response to growing demand for such money-like claims from institutional investors and firms, the shadow banking system manufactured more of this short-term debt.

Despite the prominence of this narrative in the literature, its basic premise remains untested. Did investors treat short-term debt issued by the shadow banking system as a money-like claim? The key contribution of this paper is that it is the first to show empirically that investors did indeed treat shadow bank debt as a money-like claim. It does so by documenting detailed, high-frequency, micro-evidence of tight interlinkages between the markets for Treasury bills, central bank reserves, and short-term shadow bank debt.

My approach is to first flesh out the money-creation view of shadow banking by presenting a model where the financial sector and the central bank (Federal Reserve) jointly respond to the demand for money-like claims. The model generates predictions about the prices and quantities of Treasury bills, reserves, and shadow bank debt. I then document that the model's predictions are borne out in data from the period before the 2007-2009 financial crisis.

In the model, there are three claims that provide monetary services: traditional bank deposits, Treasury bills, and shadow bank debt. Households are willing to pay a premium for such claims, some of which the financial sector can endogenously produce. The model has two key, novel features. First, different claims deliver different amounts of monetary services. Second, the model links the demand for monetary services to monetary policy because banks demand central bank reserves when they issue deposits. The Federal Reserve sets the amount of reserves to implement its target policy rate. 
A critical insight that emerges from the model is that if deposits, Treasury bills, and shadow bank debt all deliver monetary services, then the behavior of prices and quantities across the markets for these claims will be interlinked. In particular, increased demand for monetary services will be associated with (i) high prices (low yields) on claims that provide monetary services and (ii) an endogenous increase in the supply of those claims by the financial sector and the Federal Reserve. This has the following cross-market implications:

- Low yields on Treasury bills should be associated with the issuance of shadow bank debt.

- The issuance response of the shadow banking system should be concentrated in shortmaturity debt.

- Low yields on Treasury bills should be associated with open market operations that increase the supply of reserves.

- Low yields on Treasury bills should be associated with high federal funds rates relative to the target policy rate.

The first prediction is driven by the fact that investors treat shadow bank debt and Treasury bills as (imperfect) substitutes in the model. When the demand for Treasury bills is high, as reflected by low Treasury bill yields, the demand for shadow bank debt is also high. The shadow banking system accommodates this demand by increasing issuance.

The last three predictions explicitly connect the demand for shadow bank debt and Treasury bills to the demand for monetary services. Investors in the model demand shadow bank debt and Treasury bills at times when they highly value liquidity and central bank reserves.

I evaluate these predictions in the data. A critical empirical difficulty is that lowfrequency variation in the demand for money-like claims is likely to be driven by changing economic fundamentals, and thus is difficult to separate from broader macroeconomic conditions. Therefore, I focus on relatively high-frequency, weekly variation. This variation, driven by the need to make payments, manage payroll and inventories, pay dividends, and transact more broadly, is easier to isolate from background changes in economic conditions. 
Many of the empirical specifications utilize weekly data with year-month fixed effects to isolate this high-frequency variation. The analysis focuses on asset-backed commercial paper (ABCP) because data is more readily available for $\mathrm{ABCP}$ than for the other major type of short-term shadow bank debt, repurchase agreements (repo). Moreover, Krishnamurthy, Nagel, and Orlov (2013) argue that ABCP was a larger source of short-term financing for the shadow banking system than repo was.

I examine the pre-crisis period from July 2001, when weekly data first became available, through June 2007, just before the collapse of the ABCP market at the beginning of the financial crisis. The empirical evidence supports the model. Each of the model's predictions is borne out in the data. In addition, I also provide evidence that the results cannot be explained by the alternative explanation that ABCP issuance is driven by the financial sector's need for financing.

The results provide strong evidence that investors treated ABCP as a money-like claim, thus substantiating the basic premise of many explanations for the growth of shadow banking. An extrapolation from my high-frequency estimates suggests that a sustained increase in money demand could explain up to $50 \%$ of the growth in ABCP in the years before the financial crisis. Consistent with the idea that money demand played an important role in the growth of $\mathrm{ABCP}$ in the pre-crisis period, I provide evidence that the elasticity of $\mathrm{ABCP}$ supply has increased over time. Thus, the same demand shock now produces a larger increase in the quantity of short-term debt. The growth of securitization, by increasing the supply of collateral available to back ABCP, likely played an important role in increasing the elasticity of supply.

Overall, the results suggest that the demand for money-like claims was a significant driver of the growth of shadow banking in the pre-crisis period. This paper makes two main contributions relative to the existing literature on safe assets (e.g., Gorton and Metrick, 2010a; Gorton, Lewellen, and Metrick, 2011; Krishnamurthy and Vissing-Jorgensen, 2013). First, it provides evidence that the growth of shadow banking was driven by demand for claims that provide money services, as opposed to claims that are simply short term. The existing literature shows that Treasury bills are substitutes for privately issued short-term debt, but does not empirically identify reasons that investors treat these claims as substitutes. 
In contrast, this paper provides evidence that investors treat these claims as substitutes because the claims provide money services. It does so by considering the behavior of the Federal Reserve and analyzing the market for reserves, which is novel both theoretically and empirically.

The second respect in which the paper is unique is in its focus on the shadow banking system, as opposed to traditional commercial banks. Many financial innovations have affected the ability of the financial system to provide liquidity over time, but I focus on $\mathrm{ABCP}$ and the shadow banking system for two reasons. First, they played a central role in the financial crisis. Attempts to understand the origins of the crisis, as well as regulations to avoid future crises, require a better grasp of what drove the growth of the shadow banking system. Second, the growth of ABCP is representative of a broader shift in financial intermediation from traditional commercial banks to securities markets. It is important for both financial and monetary economics to better understand the extent to which these markets can perform the same functions as banks. I show that the financial system responds to shocks to the demand for money-like claims even when the central bank succeeds at pinning the policy rate at its target. The results are relevant to the conduct of monetary policy, particularly now that financial stability has become a critical focus for central banks in the aftermath of the crisis.

\section{$1 \quad$ Model}

\subsection{Setup}

I begin by presenting a model to help understand the patterns that would arise in the data if investors and households regarded ABCP as a money-like claim. There are three sets of agents in the model: households, banks, and the monetary authority (i.e., the Federal Reserve). For simplicity, all agents are risk neutral. 


\subsubsection{Household demand}

There are three types of claims that provide money services in the economy: deposits, Treasury bills, and asset-backed commercial paper (ABCP). Assume that each claim provides a different amount of monetary services. A dollar of deposits provides a quantity of these services $\alpha_{D}$, which I normalize to 1. A dollar of Treasury bills provides $\alpha_{T}>0$ of monetary services. Finally, a dollar of ABCP provides $\alpha_{A B C P}>0$ of monetary services.

Denote the dollar (principal) amount of deposits $m_{D}$, the dollar amount of Treasury bills $m_{T}$, and the dollar amount of ABCP $m_{A B C P}$. Assume that the total amount of effective money services in the economy aggregates with a constant elasticity of substitution as

$$
M=\left(m_{D}^{\frac{\sigma-1}{\sigma}}+\alpha_{T} m_{T}^{\frac{\sigma-1}{\sigma}}+\alpha_{A B C P} m_{A B C P}^{\frac{\sigma-1}{\sigma}}\right)^{\frac{\sigma}{\sigma-1}}
$$

where $\sigma$ is the elasticity of substitution between deposits, Treasury bills, and ABCP. ${ }^{1}$ Households have downward-sloping demand for these services. In particular, following Krishnamurthy and Vissing-Jorgensen (2012), I assume that households maximize $E\left[\sum \beta^{t} C_{t}\right]$, where $C_{t}=c_{t}+\theta v(M) . v(M)$ is a reduced-form function for the utility from consuming total money services $M$, and $\theta>0$ is a money demand shifter - a notational device that allows us to examine the effects of an increase in demand for all money-like claims simply by taking comparative statics with respect to $\theta$. In the Internet Appendix, I show that households with this utility specification require gross returns

$$
\begin{array}{ll}
R_{D}=R-\theta v^{\prime}(M)\left(\frac{M}{m_{D}}\right)^{1 / \sigma} & \text { for deposits, } \\
R_{T}=R-\alpha_{T} \theta v^{\prime}(M)\left(\frac{M}{m_{T}}\right)^{1 / \sigma} & \text { for Treasury bills, and } \\
R_{A B C P}=R-\alpha_{A B C P} \theta v^{\prime}(M)\left(\frac{M}{m_{A B C P}}\right)^{1 / \sigma} & \text { for ABCP, }
\end{array}
$$

where $R$ is the gross return for claims that are not money-like. The gross return on money-like claims is lower than $R$ because households derive additional utility from money services. I call the difference between the returns required on money-like claims and the return required

\footnotetext{
${ }^{1}$ Why might these claims be imperfect substitutes? One answer is that the types of money services they provide are different. Treasury bills and ABCP provide safety and liquidity, while deposits provide safety, liquidity, and transaction services (e.g., check writing).
} 
on non-money claims the money premium. Note that the premium is given by the marginal value of money services provided by a particular claim. ${ }^{2}$ For instance, the money premium for $\mathrm{ABCP}$ is given by

$$
\frac{\partial}{\partial m_{A B C P}}[\theta v(M)]=\theta v^{\prime}(M) \frac{\partial M}{\partial m_{A B C P}}=\alpha_{A B C P} \theta v^{\prime}(M)\left(\frac{M}{m_{A B C P}}\right)^{1 / \sigma} .
$$

The comparative statics derived below will focus on the effects of variation in the demand shifter $\theta$. Assume that $v^{\prime}>0$ and $v^{\prime \prime}<0$ so that money services provide positive but decreasing marginal utility.

\subsubsection{Supply of Money-like Claims}

The money-like claims households value are produced by the government, which controls the quantity of Treasury bills, and banks, which can produce deposits and ABCP. ${ }^{3}$ I take the supply of Treasury bills as exogenous. Below, I argue that this assumption is reasonable for the high-frequency variation on which the empirics rely.

Assume that there is a continuum of banks of mass one. Each bank is small and thus takes the aggregate quantity of money services and the prices of money-like claims as given. On the asset side, banks may hold reserves or invest in productive projects. Assume that the return on reserves is zero, while the return on productive projects is $F>R$ in expectation. On the liability side, banks can finance themselves from three sources: (i) equity or longterm bonds, ${ }^{4}$ (ii) deposits, and (iii) ABCP. Assume that the size of each bank's balance sheet is fixed in the short run, so that banks simply pick the composition of their assets and liabilities. 5

Let $\widehat{r}$ be the fraction of a bank's assets held as reserves, $\widehat{m_{D}}$ be the fraction of its liabilities

\footnotetext{
${ }^{2}$ Nagel (2014) argues that the level of short-term interest rates plays an important role in determining this premium at low frequencies.

${ }^{3}$ In practice, the distinction between traditional commercial banks and shadow banks is somewhat blurred. There are small commercial banks, which only issue deposits, standalone shadow banks, investment vehicles which only issue ABCP, and large financial institutions, which do both. For simplicity, the banks we model issue both deposits and ABCP.

${ }^{4}$ There is no distinction in pricing between bonds and equity in the model since we assume households are risk-neutral.

${ }^{5}$ This assumption simplifies the analysis by eliminating a variable but is not crucial. Similar results would obtain if we had banks pick the size of their balance sheets as well.
} 
that are deposits, and $\widehat{m_{A B C}}$ be the fraction of its liabilities that are ABCP. Then the bank's balance sheet is given by

\begin{tabular}{lc|lc}
\multicolumn{2}{c|}{ Assets } & \multicolumn{2}{|c}{ Liabilities } \\
\hline Projects & $(1-\widehat{r})$ & Long-term bonds & $\left(1-\widehat{m_{D}}-m_{A B C P}\right)$ \\
Reserves & $\widehat{r}$ & Deposits & $\widehat{m_{D}}$ \\
& & ABCP & $\widehat{m_{A B C}}$
\end{tabular}

Each bank chooses $\widehat{r}, \widehat{m_{D}}$, and $\widehat{m_{A B C}}$ to maximize its profits. Long-term debt provides no money services and, therefore, requires gross return $R$. By issuing deposits and ABCP, banks can lower their funding costs, capturing the money premium associated with each claim. However, issuing either deposits or ABCP each comes at a cost. Assume that raising $\mathrm{ABCP}$ has a private cost from the bank's perspective of $c\left(\widehat{m_{A B C}}\right)$. As discussed in Section 4.2, the effects of innovations like securitization that make it less costly to issue ABCP can be captured by thinking about changes in $c(\cdot)$.

The cost of raising deposits comes from the fact that the bank needs to hold reserves at the Federal Reserve to protect itself from the payment-related uncertainty generated by deposits. Specifically, since deposits are demandable, the daily payment-related inflows and outflows associated with them cannot be perfectly forecasted. These inflows and outflows change the bank's net balance in its account with the Federal Reserve, and it is costly for the bank to end the day with a negative balance because there are significant overdraft fees. As a result, when they issue deposits, banks hold reserves as a precaution against overdrafting their accounts with the Federal Reserve. ${ }^{6}$ Let $r^{*}\left(\widehat{m_{D}}\right)$ be the quantity of precautionary reserves that banks endogenously choose to hold. I assume that $r^{* \prime}(\cdot)>0$ so that precautionary reserves are increasing in the amount of deposits issued by the bank. In the Internet Appendix, I provide a microfoundation for this assumption.

Reserves are costly to obtain because they are in fixed supply: the Federal Reserve sets the total quantity of available reserves, $\mathcal{R}$. Thus, to hold reserves, banks must purchase

\footnotetext{
${ }^{6}$ Banks may also choose to hold reserves against their ABCP liabilities. However, these reserves are likely to be smaller than the reserves held against deposits, because unlike deposits ABCP is not immediately demandable. We can think of $\widehat{r}$ as the incremental reserves banks choose to hold against deposit liabilities over and above reserves held against other liabilities.
} 
them in the interbank market. The cost of purchasing reserves in the interbank market is the federal funds rate. Assume the Federal Reserve endogenously sets the quantity of reserves in the banking system $\mathcal{R}^{*}(i)$ to implement its target federal funds rate $i$. Further, assume that the target rate $i$ is derived from a Taylor (1993)-style rule, reflecting inflation and output-gap concerns outside the model, not the short-run money demand considerations isolated in the empirics.

\subsubsection{Discussion of Model Setup}

Before solving the model, a few aspects of the setup are worth discussing. First, the level of demand for money-like claims $\theta$ is modeled in reduced form. Many models of money demand, including Baumol (1952) and Tobin (1956) among others, derive demand in an optimizing framework where households trade off the lower interest paid by money-like claims against their need to transact. My focus is on variation in demand over time and the supply response of the shadow banking system, so a simpler model where demand can be varied with a single parameter $(\theta)$ is sufficient. Relatedly, I take no stand on the source of variation in money demand from the household sector. The household sector can be broadly thought of as a proxy for actual households, non-financial corporations, and unmodeled parts of the financial system. Thus, variation in demand could stem from payrolls, inventories, dividends, and certain transactions in financial markets, among other sources.

Second, I take the money services provided by ABCP, $\alpha_{A B C P}$, as given. Why might ABCP provide money services? First, its short-term safety makes it a good store of value. ABCP is typically backed by securitized bonds that are themselves AAA rated. In addition,

virtually all ABCP programs are covered by guarantees from their sponsoring institutions to protect investors from loss. A second characteristic of ABCP that may provide money services is its liquidity. While secondary markets for commercial paper are not highly liquid (Covitz and Downing, 2007), the short maturity of ABCP allows investors to convert it into cash for transactions on short notice. Given that the underlying securitized bonds also appear to have relatively illiquid secondary markets (Bessembinder, Maxwell, and Venkataraman, 2013), this "liquidity through maturity" of ABCP may be important for its provision of money services. 
A third feature of the model setup meriting discussion is the treatment of reserves. In practice, the demand for reserves in the federal funds market is ultimately driven by two sources: reserve requirements and payments and clearing. Reserve requirements apply to transaction deposits at all depository institutions (Board of Governors, 2005). However, banks have found ways to avoid reserve requirements, weakening their bite over time. Thus, reserve demand from banks is modeled as being driven by payments between banks. ${ }^{7}$ When clients use their deposits for payments, banks use the federal funds market to transfer the funds. Specifically, the bank of the payer sends reserves to the bank of the payee. This reduces the quantity of reserves in the account of the bank of the payer at the Federal Reserve, and increases the quantity of reserves in the account of the bank of the payee. These transactions leave the total quantity of reserves unchanged in the aggregate because reserve balances are deducted from one bank and credited to another in any transaction.

However, according to the Federal Reserve, "a depository institution may aim to hold some positive excess reserve balances at the end of the day as additional protection against an overnight overdraft in its account." Thus, because banks that end up with negative balances in their accounts at the Federal Reserve are charged overdraft fees, transactions affect the aggregate demand for reserves. When they anticipate transactions, as they will when they have large deposit liabilities, banks will hold reserves as a precaution against overdrafts. See Poole (1968) and Ho and Saunders (1984), as well as the Internet Appendix of this paper, for theoretical models of this phenomenon. Carpenter and Demiralp (2006) provide empirical evidence, arguing that "because banks use their Federal Reserve accounts to clear transactions for themselves and their customers, the demand for reserves tends to be higher on days with large expected volumes of payments."

\footnotetext{
${ }^{7}$ In practice,the reserve requirement depends on the deposits issued over a prior period. This means that a shock to the demand for money services creates demand for reserves at two horizons. Payments-driven precautionary demand for reserves is contemporaneous with the shock to money demand. Demand driven by reserve requirements follows the shock to money demand with a lag. Reserve-requirement driven demand can be incorporated into the model by adding a second period. The first period would be similar to the existing model, with a random realization of money demand $\theta$. This realization of money demand would drive precautionary demand for reserves in the first period and reserve-requirement based demand for reserves in the second period.
} 


\subsection{Equilibrium}

I now solve for the equilibrium. First consider the problem of an individual bank and then the problem of the Federal Reserve. Individual banks take the aggregate money quantities $M, m_{D}, m_{T}$, and $m_{A B C P}$, as well as the prevailing federal funds rate $\widehat{i}$, as given. In addition, the model parameters $i, \theta, \sigma, v(\cdot), r^{*}(\cdot), F, c(\cdot)$, and $R$ are taken as given. Thus, individual banks are price takers and take the required returns $R_{A B C P}$ and $R_{D}$ as given, even though those required returns are determined by aggregate issuance decisions in equilibrium.

Banks solve for their individually optimal quantities of $\mathrm{ABCP}\left(\widehat{m_{A B C P}}\right)$, deposits $\left(\widehat{m_{D}}\right)$, and reserves $(\widehat{r})$. Since the mass of banks is 1 , in equilibrium aggregate quantities satisfy $m_{D}=\widehat{m_{D}}, m_{A B C P}=\widehat{m_{A B C P}}$, and $M=\left(m_{D}^{\frac{\sigma-1}{\sigma}}+\alpha_{T} m_{T}^{\frac{\sigma-1}{\sigma}}+\alpha_{A B C P} m_{A B C P}^{\frac{\sigma-1}{\sigma}}\right)^{\frac{\sigma}{\sigma-1}}$. An individual bank's problem is

$\max _{\widehat{r}, m_{D}, m_{\widehat{A B C} P}} \overbrace{F \cdot(1-\widehat{r})}^{\text {Asset Return }}-\overbrace{R+\widehat{m_{D}} \cdot\left(R-R_{D}\right)+\vec{m}_{\widehat{A B C} P} \cdot\left(R-R_{A B C P}\right)}^{\text {Cost of Funding }}-\overbrace{c\left(m_{\widehat{A B C} P}\right)}^{\text {Cost of ABCP }}-\overbrace{\widehat{r} \cdot \widehat{i}}^{\text {Cost of Reserves }}$

subject to the constraints

$$
\widehat{r}=r^{*}\left(\widehat{m_{D}}\right) \text { and } \widehat{m_{D}}+\widehat{m_{A B C P}} \leq 1
$$

If banks are at an interior optimum in their capital structure decisions so that $\widehat{m_{D}}+m_{A B C P}<$ 1 holds strictly, then the equilibrium is simple.

The first order condition for $\widehat{m_{D}}$ implies

$$
\widehat{i}+F=\frac{R-R_{D}}{r^{* \prime}\left(\widehat{m_{D}}\right)}=\frac{1}{r^{* \prime}\left(\widehat{m_{D}}\right)} \theta v^{\prime}(M)\left(\frac{M}{m_{D}}\right)^{1 / \sigma}
$$

The benefit of adding a unit of deposits is that the bank can capture the money premium that deposits carry, $\theta v^{\prime}(M)\left(\frac{M}{m_{D}}\right)^{1 / \sigma}$. The cost of adding this unit of deposits is that $r^{* \prime}\left(\widehat{m_{D}}\right)$ reserves must be purchased in the interbank market, and $r^{* \prime}\left(\widehat{m_{D}}\right)$ fewer units of productive projects are held on the bank's balance sheet. ${ }^{8}$ Thus, the prevailing federal funds rate $\widehat{i}$ is

\footnotetext{
${ }^{8}$ The fact that adding reserves forces the bank to forego productive investment is a product of the assumption that the bank's balance sheet is fixed in the short run. In a model where banks can adjust the sizes of their balance sheets, this effect would vanish.
} 
linked to the money premium on deposits through reserve holdings.

The first order condition for $\widehat{m A B C}$ is simply

$$
c^{\prime}\left(\widehat{m_{A B C P}}\right)=R-R_{A B C P}=\alpha_{A B C P} \theta v^{\prime}(M)\left(\frac{M}{m_{A B C P}}\right)^{1 / \sigma} .
$$

For the bank, the benefit of adding a unit of ABCP is the money premium that ABCP carries, $\alpha_{A B C P} \theta v^{\prime}(M)\left(\frac{M}{m_{A B C P}}\right)^{1 / \sigma}$. The marginal cost is $c^{\prime}\left(\widehat{m_{A B C P}}\right)$.

To compute the equilibrium, first note that market clearing for reserves and symmetry imply $r^{*}\left(\widehat{m_{D}}\right)=\mathcal{R}$, where $\mathcal{R}$ is the aggregate quantity of reserves in the interbank market. Denote the equilibrium quantity of deposits $m_{D}^{*}(\mathcal{R})=r^{*-1}(\mathcal{R})$ and define

$$
M^{*}(\mathcal{R})=\left(m_{D}^{*}(\mathcal{R})^{\frac{\sigma-1}{\sigma}}+\alpha_{T} m_{T}^{\frac{\sigma-1}{\sigma}}+\alpha_{A B C P} m_{A B C P}^{\frac{\sigma-1}{\sigma}}\right)^{\frac{\sigma}{\sigma-1}}
$$

Substituting this into the first order condition for $\widehat{m_{D}}$ yields

$$
\widehat{i}+F=\frac{\theta v^{\prime}\left(M^{*}\right)}{r^{* \prime}\left(m_{D}^{*}\right)}\left(\frac{M^{*}}{m_{D}^{*}}\right)^{1 / \sigma}
$$

which determines the prevailing federal funds rate $\widehat{i}$ as a function of the quantity of reserves $\mathcal{R}$. Finally, the Federal Reserve endogenously sets the quantity of reserves $\mathcal{R}^{*}(i)$ to implement the target federal funds rate $\widehat{i}=i$. That is, $\mathcal{R}^{*}(i)$ is implicitly defined by

$$
i+F=\frac{\theta v^{\prime}\left(M^{*}\left(\mathcal{R}^{*}(i)\right)\right)}{r^{* \prime}\left(m_{D}^{*}\left(\mathcal{R}^{*}(i)\right)\right)}\left(\frac{M^{*}\left(\mathcal{R}^{*}(i)\right)}{m_{D}^{*}\left(\mathcal{R}^{*}(i)\right)}\right)^{1 / \sigma} .
$$

The following proposition summarizes the equilibrium.

Proposition 1 The market equilibrium is given by Equations (8) and (11), which together define a fixed point in $\mathcal{R}$ and $\widehat{m_{A B C}}=m_{A B C P}$.

Proof. All proofs are given in Appendix $C$.

\subsubsection{Comparative Statics}

Now consider how prices and quantities vary in the model with the level of money demand, $\theta$. I begin by characterizing the supply response of the Federal Reserve and banking system 
to higher levels of money demand. The following proposition characterizes their response.

Proposition 2 Suppose the elasticity of substitution between deposits and ABCP is $\sigma>1$. Then the Federal Reserve and the banking system respond to higher levels of money demand $\theta$ by increasing the supply of reserves and $A B C P$ respectively. Formally, $\partial \mathcal{R}^{*} / \partial \theta>0$ and $\partial m_{A B C P} / \partial \theta>0$.

The key intuition behind the Federal Reserve's response is that it keeps the federal funds rate at its target. The prevailing federal funds rate $\hat{i}$ is determined by the money premium on deposits, $\theta v^{\prime}(M)\left(M / m_{D}\right)^{1 / \sigma}$. Increasing the level of money demand $\theta$ increases this premium, holding fixed $M$ and $m_{D}$. Thus, banks will wish to issue more deposits to capture this larger premium. This raises their demand for reserves and thus the prevailing federal funds rate. To push the rate down to the target $i$, the Federal Reserve must then increase the supply of reserves.

The ABCP supply response is driven by similar logic. For higher values of $\theta$, banks can capture a larger money premium by issuing $\mathrm{ABCP}$, and therefore issue more $\mathrm{ABCP}$. The total supply response of banks and the Federal Reserve drives down the money premium on deposits until $\theta v^{\prime}(M)\left(M / m_{D}\right)^{1 / \sigma}$ has the same value it did previously, so that the federal funds rate remains at its target.

Note that since deposits and $\mathrm{ABCP}$ are imperfect substitutes, control over the federal funds rate does not give the Federal Reserve control over the quantity of ABCP produced. The increase in reserve supply does not fully crowd out the banking sector's production of $\mathrm{ABCP}$.

What is the level of the T-bill yields after these supply responses by the Federal Reserve and the banking sector? The following proposition shows that higher levels of money demand $\theta$ are associated with lower equilibrium yields, despite the supply responses.

Proposition 3 Suppose there is an increase in $\theta$. After the supply responses of the Federal Reserve and the banking system, the equilibrium T-bill yield $R_{T}$ is lower than its initial level. Formally, $\partial R_{T} / \partial \theta<0$ if $\sigma>1$.

This result relies on the assumption that deposits are imperfect substitutes for Treasury bills and $\mathrm{ABCP}$. After an increase in money demand $\theta$, yields fall. The Federal Reserve 
increases the supply of reserves to push the federal funds rate back to its target. However, since deposits are imperfect substitutes for Treasury bills and ABCP, this increase in the supply of reserves does not fully restore yields on Treasuries and ABCP to their initial levels. Similarly, Treasuries and ABCP are imperfect substitutes, so the banking sector's ABCP supply response does not fully restore the T-bill yield, $R_{T}$, to its original level either.

Finally, consider the effect of increasing the supply of Treasury bills. The following proposition shows that this has similar effects to decreasing the level of money demand $\theta$.

Proposition 4 Suppose there is an increase in Treasury bill supply $m_{T}$. The banking system responds by decreasing the supply of $A B C P$, and the equilibrium T-bill yield $R_{T}$ increases. Formally, $\partial m_{A B C P} / \partial m_{T}<0$ and $\partial R_{T} / \partial m_{T}>0$ if $\sigma$ is sufficiently large.

The intuition here is that increasing the supply of Treasury bills increases the overall supply of money services. This decreases the marginal value of money claims. In turn, this smaller money premium reduces the incentives for banks to issue ABCP, so they decrease the quantity outstanding. Essentially, increases in Treasury bill supply reduce the residual demand for money-like claims that is not met by Treasury bills.

\section{Empirics}

In the empirics, I evaluate these propositions using a weekly data set beginning in July 2001, when 4 -week bills were reintroduced to the set of Treasury securities. I focus on the pre-crisis period and end the sample in June 2007, just before the collapse of the ABCP market. Table 1 presents summary statistics. The paper presents results for the entire sample period, but in untabulated results I find similar results when I examine the 2001-2004 and 2004-2007 subperiods separately.

Using high-frequency (weekly) data has two main advantages. First, six years of weekly data gives us a reasonably long time dimension to work with. Second, low-frequency variation that may be due to changing macroeconomic conditions can be eliminated. For instance, Figure 1 shows that there is a time trend in ABCP outstanding over the sample period. Furthermore, the trend is not linear so a simple linear control will not fully absorb it. I will 
use weekly differences, which render the variables stationary, and year-month fixed effects to eliminate this kind of variation.

\subsection{Taking the Model to Data}

To operationalize the model for empirical work, suppose that there are two sources of exogenous variation: (i) variation in overall money demand $\theta$ and (ii) variation in the supply of Treasury bills $m_{T}$. In general, these sources of variation are not exogenous. Money demand is a function of output and thus the state of the macroeconomy. Similarly, the government tends to run budget deficits during recessions, at low frequencies, so the supply of Treasury bills may tend to rise in bad times.

However, at the weekly frequencies studied, variation in money demand is driven by factors like weekly and bi-weekly payroll, inventory management, dividend payments, and financial market transactions (Poole and Lieberman, 1972; Cochrane, 1989; Faig, 1989). Similarly, as pointed out by Duffee (1996), Gurkaynak, Sack, and Wright (2006), and Greenwood, Hanson, and Stein (2013), there is seasonal variation in the Treasury bill market at the weekly level due to tax receipts and government outlays. This type of variation, which the empirics seek to isolate, is more likely to satisfy identifying restrictions than is lower-frequency variation.

Taking shocks to money demand $\theta$ and Treasury bill supply $m_{T}$ as the sources of variation, the model generates the following predictions:

- Prediction 1: Propositions 2 and 3 imply that low yields on Treasury bills should forecast $\mathrm{ABCP}$ issuance. An increase in money demand $\theta$ lowers T-bill yields. In response to high demand, banks should issue ABCP. Put differently, increased demand should raise both quantities and prices, and low T-bill yields are a proxy for high prices.

- Prediction 2: Proposition 4 implies that Treasury bill issuance and ABCP issuance should be negatively correlated. If ABCP and T-bills are substitutes, an increase in Treasury bill supply $m_{T}$ should crowd out ABCP issuance.

Predictions 1 and 2 stem from the fact that ABCP and T-bills are partial substitutes in the model: both claims can satisfy the demand for money-like claims. 
Crucially, the model also provides predictions that explicitly link the common demand for ABCP and T-bills to the demand for money services. This is important because it is difficult to directly verify that ABCP provides money services. The following predictions draw the link indirectly: ${ }^{9}$

- Prediction 3: The issuance of short maturity ABCP should respond most strongly to T-bill yields. Shorter maturity ABCP should provide more money services (i.e., have higher values of $\alpha_{A B C P}$ ) and therefore should respond more strongly to money demand shocks. ${ }^{10}$

- Prediction 4: Propositions 2 and 3 imply that low T-bill yields should forecast increases in the supply of reserves by the Federal Reserve. In the model, low T-bill yields indicate high money demand $\theta$ and thus high reserve demand. To keep the federal funds rate at its target, the Federal Reserve must accommodate this demand by increasing the supply of reserves.

- Prediction 5: Finally, the expression for the prevailing federal funds rate (7) shows that if the Federal Reserve does not perfectly stabilize the funds rate, it should be high when the T-bill yield is low. ${ }^{11}$ In the model, high money demand $\theta$ is associated with low T-bill yields and high values of the federal funds rate $\widehat{i}$ before the Federal Reserve adjusts the supply of reserves appropriately. The federal funds rate is essentially the cost of an input (reserves) needed to create more money-like assets.

\section{$2.2 \quad$ Alternative Explanations}

Before proceeding, it is worth briefly discussing the main alternative explanation I hope to rule out. The main alternative is that high-frequency changes in ABCP supply, rather

\footnotetext{
${ }^{9}$ The predictions about open market operations and central bank reserves make the indirect link as direct as possible. Reserves are at the very heart of the formal money supply.

${ }^{10}$ In the Internet Appendix, we extend the model to allow banks to issue different types of ABCP that deliver different amount of money services and formally prove this result.

${ }^{11}$ This would be the case, for instance, in the presence of unanticipated shocks to money demand. In the model, the Federal Reserve can keep the federal funds rate exactly at the target because money demand $\theta$ is known exactly. In practice, however, $\theta$ may not be perfectly observable. There are both expected and unexpected shocks to money demand - for instance, Hamilton $(1996,1997)$ uses Federal Reserve daily errors in forecasting the supply and demand for reserves to show that the federal funds rate is decreasing in the quantity of reserves supplied.
} 
than demand, drive the empirical results. Under this alternative, ABCP provides no money services, and issuance is driven by banks' need for financing at high frequencies.

The critical distinction between the money demand-based explanation formalized in the model and the supply alternative is the following. Under the supply alternative, there are no linkages between the markets for ABCP and Treasury bills and no linkages between the markets for central bank reserves and Treasury bills. This has two implications. First, the supply of Treasury bills should not be correlated with the supply of ABCP and reserves at high frequencies. Put differently, if ABCP, deposits, and T-bills are not substitutes, then there is no reason for banks to avoid issuing ABCP and deposits in weeks when T-bill issuance is high. Second, yields on Treasury bills should not be correlated with ABCP issuance at high frequencies. If anything, a flight to quality story would imply that T-bill yields should be low in bad times, when banks have fewer loans to finance. Thus, under the flight to quality alternative hypothesis, T-bill yields should be positively correlated with ABCP issuance, the opposite of what the money demand story predicts.

In contrast, under the money demand explanation, Treasury bill yields should reflect demand for money services and should therefore be correlated with the supply of ABCP and reserves. In the empirics, I show that this is the case: the information in T-bill yields alone is useful for forecasting the supply of $\mathrm{ABCP}$ and reserves at high frequencies.

\section{$2.3 \quad$ Data}

The data come from several sources. Interest rates are from the Federal Reserve H.15 Statistical Release. Data on ABCP outstanding comes from the Commercial Paper Rates and Outstanding Summary, also a Federal Reserve Board Statistical Release. Data on open market operations come from the Federal Reserve Bank of New York. Weekly data on Treasury bills outstanding are from the US Treasury Office of Debt Management. Data on monetary aggregates are from the Federal Reserve H.6 Statistical Release.

The overnight indexed swap (OIS) rate, which is obtained from Bloomberg, will play an important role in the empirics. The OIS rate represents the expected average of the federal funds rate over a given term. ${ }^{12}$ Like most swaps, no cash is exchanged at the initiation of an

\footnotetext{
${ }^{12}$ Formally, the OIS rate is the fixed rate in a fixed-to-floating interest rate swap. When two counterparties
} 
OIS contract, and at maturity only the required net payment is made. Thus, OIS contracts carry little credit risk and are a good proxy for risk-free rates purged of liquidity and credit risk premia (Brunnermeier, 2009; Duffie and Choudry, 2011; Feldhutter and Lando, 2008; Gorton and Metrick, 2010a; Schwarz, 2010 ). Moreover, since no cash is exchanged up-front, OIS is not a rate at which banks can raise funding. For these reasons, it serves as a suitable a baseline for the overall level of short-term interest rates. In particular, the T-bill - OIS spread should capture the information in T-bill yields about the money premium. ${ }^{13}$ Using the T-bill - OIS spread essentially strips out variation in the T-bill yield driven by changes in the overall level of short-term interest rates.

\section{$2.4 \quad$ Results}

\subsubsection{ABCP Issuance Decreases with T-bill Yields}

I now turn to the empirical results. Table 2 Panel A examines Prediction 1: low T-bill yields should forecast ABCP issuance. In the model, low yields indicate high money demand because investors are particularly willing to pay for the incremental money services provided by Treasury bills. The shadow banking sector should respond to this increased demand by issuing more ABCP.

To examine this prediction, I examine the relationship between net $\mathrm{ABCP}$ issuance and the T-bill - OIS spread. Specifically, I run the following regression:

$$
\Delta \ln (\text { ABCP Outstanding })=\alpha+\beta \cdot T \text {-bill }-O I S_{t-1}+\varepsilon_{t}
$$

The first column shows the raw relationship, which is strongly negative and significant as predicted by the model. When money demand is high, T-bill yields are low, and issuance is high. When money demand is low, T-bill yields are high, and issuance is low. Figure

enter into the swap, one agrees to pay the OIS rate and in return receive the geometric average of the daily overnight Federal Funds rate over the term of the contract. Thus, the OIS rate should represent the average of the Federal funds rate over the term of the contraction. There may be a small term premium component as well, but over the 1-month horizon we focus on, this is likely to be negligible.

${ }^{13}$ In the Internet Appendix, we show that we obtain similar results if we use the spread between the Federal Funds target rate and T-bill yields. The difference between using the target rate and OIS is that OIS correctly reflects short-term expected changes in the target. 
2 presents this relationship as a scatterplot. The second column adds year-month fixed effects to show that the relationship is not driven by low-frequency common trends in ABCP outstanding and the T-bill - OIS spread. The remainder of the table shows that the results are also robust to controlling for the lagged level of $\mathrm{ABCP}$ outstanding, lagged $\mathrm{ABCP}$ issuance, and week-of-year fixed effects. This shows that the results are not simply capturing some kind of mechanical mean reversion or predictable weekly pattern in ABCP issuance and spreads.

The magnitudes of the effects are economically plausible. Spreads are measured in percentage points, so the regressions imply that a $1 \%$ lower spread is associated with $1-2 \%$ more ABCP issuance. In the pre-crisis period, the T-bill - OIS spread has a mean of -23 basis points (bps) and a standard deviation of 19 bps. Of course, it would be surprising if the magnitudes were very large, given that I am examining high-frequency variation.

The small magnitudes are also reassuring because they admit a plausible mechanism through which the shadow banking system can adjust to changing money demand. In the model, banks adjust by changing their mix of long-term debt versus short-term deposit and $\mathrm{ABCP}$ financing. In practice, it may be unlikely that banks alter their long-term debt issuance in response to week-to-week changes in money demand. However, other types of issuers in the shadow banking system are able to more quickly respond. Over 30\% of ABCP in the precrisis period was issued by issuers that purchase securities on the secondary market. These issuers, including securities arbitrage programs, structured investment programs, and collateralized debt obligations, can quickly respond to money demand shocks by financing secondary market purchases of the underlying securitized bonds with short-term ABCP (Covitz, Liang, and Suarez, 2013).

Table 2 Panel B shows that the results are robust to using an alternative measure of the premium on Treasury bills, the z-spread. The z-spread is the spread between actual T-bill yields and fitted yields from a spline. The fitted yields are constructed based on Gurkaynak, Sack, and Wright (2006), who estimate the Treasury yield curve using only Treasury notes and bonds with remaining maturities greater than three months. Thus, the z-spread is a measure of the deviation of actual T-bill yields from an extrapolation based on the rest of the yield curve. Consistent with the idea that Treasury bills provide greater money services than 
long-term Treasuries, fitted yields are typically significantly higher than actual yields. Table 2 Panel B shows that low z-spreads forecast ABCP issuance, consistent with the predictions of the paper. When T-bills are particularly expensive relative to longer term Treasuries, this is a sign that money markets are tight. The banking sector then responds by issuing more $\mathrm{ABCP}$.

\subsubsection{Treasury Bills and ABCP Issuance}

I next turn to Prediction 2: Treasury bill issuance and ABCP issuance should be negatively correlated. In the model, increasing the supply of Treasury bills increases the total supply of money services in the economy, driving down their marginal value. This decreases the premium on money-like claims, reducing the shadow banking system's incentive to issue ABCP.

Table 3 Panel A shows that this is the case, regressing net ABCP issuance on net Treasury bill issuance. The first column shows the raw relationship, which is negative and significant. Figure 3 presents this relationship as a scatterplot. When Treasury bill issuance is high, $\mathrm{ABCP}$ issuance is low. The remaining columns show that the results are robust to controlling for year-month fixed effects, lagged $\mathrm{ABCP}$ outstanding, lagged $\mathrm{ABCP}$ issuance, and week-of-year fixed effects. The relationship is always negative, and statistically significant

in every column except the second. Krishnamurthy and Vissing-Jorgensen (2013) provide corroborating evidence. Examining low-frequency (annual) changes, they find a negative correlation between the supply of Treasuries and the quantity of bank deposits.

In the model, the predicted negative correlation was derived by considering the response of the shadow banking system to an exogenous increase in Treasury bill supply. Is this a reasonable assumption for the empirics? To be interpreted as evidence in favor of the model, Treasury bill supply shifts at high frequencies need to be unrelated to the conditions determining ABCP issuance. High-frequency Treasury bill issuance is largely driven by seasonal variation in the government's outlays and tax receipts (Duffee, 1996; Gurkaynak, Sack, and Wright, 2006; and Greenwood, Hanson, and Stein, 2013). In particular, weekly Treasury bill supply is unlikely to be correlated with the financial system's need for financing.

Does the relationship between ABCP issuance and Treasury bill issuance line up with 
the relationship between ABCP issuance and yields in the way the model predicts? By increasing the total supply of money services, increased Treasury bill issuance should reduce their marginal value. This should increase the T-bill - OIS spread because investors then care less about the money services offered by Treasury bills. The lower marginal value of money services decreases the shadow banking system's incentives to issue ABCP.

Panel B of Table 3 shows that the data are consistent with this mechanism. I run an instrumental variables regression, regressing ABCP issuance on the T-bill - OIS spread, instrumenting for the spread with Treasury bill issuance. Relative to the results in Panel A, the new information in Panel B comes from the first stage regression, which shows that the T-bill - OIS spread does indeed increase with Treasury bill issuance as predicted by the model. Essentially, the panel shows that the timing of the relationship between spreads and ABCP issuance lines up correctly with the timing of the relationship between T-bill issuance and $\mathrm{ABCP}$ issuance. ${ }^{14}$

\subsubsection{Short-Term ABCP Responds Most}

So far I have shown that the data are consistent with the idea that ABCP is a substitute for Treasury bills. The remaining results explicitly connect the demand for Treasury bills and $\mathrm{ABCP}$ to the demand for money services.

I begin by analyzing Prediction 3: the issuance of short-maturity ABCP should respond most strongly to demand shifts. As discussed above, issuance of claims that provide the most money services should respond the most strongly to increases in money demand. It seems plausible to assume that short-maturity ABCP offers greater money services than long-maturity ABCP. Secondary markets for commercial paper are not very liquid (Covitz and Downing, 2007), so much of the liquidity of ABCP stems from the fact that it has a short maturity. Thus, the household sector should be willing to pay a particularly high money

\footnotetext{
${ }^{14}$ Note that our approach is somewhat different than a standard instrumental variables approach for identifying supply elasticities. A typical instrument would shift money demand holding other determinants of $\mathrm{ABCP}$ outstanding constant. Here we are essentially dividing money-like claims into private claims (ABCP and deposits) and government claims (Treasury bills). Any variable that shifts price while holding the private supply curve fixed (i.e., satisfying the exclusion restriction) is sufficient to identify the private supply elasticity. As argued above, the change in government supply is such a variable. Changes in Treasury supply essentially shift around the residual demand for money-like claims that is not met by Treasury bills, while holding the private supply curve constant.
} 
premium for short-maturity $\mathrm{ABCP} .{ }^{15}$

I use data on gross $\mathrm{ABCP}$ issuance from the Federal Reserve Board, which is broken out by maturity, to test this prediction in Table 4 . Panel A shows that gross issuance of very short maturity (1-4 day) ABCP responds most negatively to the T-bill - OIS spread. When T-bill yields are low, short-maturity ABCP issuance rises sharply. For longer maturities, the strength of the relationship weakens, eventually turning positive for the longest maturities. ${ }^{16}$ The relationship here is not perfectly monotonic, but the regression coefficients generally increase with maturity. Moreover, in untabulated results, I find that the weighted average maturity of ABCP issuance is negatively correlated with the T-bill - OIS spread.

\subsubsection{Open Market Operations Decrease with T-bill Yields}

I next link the demand for $\mathrm{ABCP}$ and Treasury bills to money demand by connecting it to the banking system's demand for central bank reserves. Prediction 4 is that increases in money demand should decrease the T-bill - OIS spread and lead the Federal Reserve to increase the supply of reserves. An increase in money demand increases demand for deposits. When they issue deposits, banks then wish to hold more reserves, raising the prevailing federal funds rate. In order to keep the federal funds rate at its target, the Federal Reserve injects reserves into the banking system.

Panel A of Table 5 examines this prediction, running the regression:

$$
\ln (\text { RESERVE INJECTION })=\alpha+\beta \cdot T \text {-bill }-O I S_{t-1}+\varepsilon_{t} .
$$

The first column shows the raw relationship, which is strongly negative and significant as predicted by the model. When money demand is high, T-bill yields are low, and the Federal Reserve injects more reserves. When money demand is low, T-bill yields are high, and the Federal Reserve injects fewer reserves. Figure 4 presents this relationship as a scatterplot.

\footnotetext{
${ }^{15}$ The logic of Modigliani-Miller (1958) would imply that the shadow banking system should be indifferent to issuing different types of ABCP. However, this logic breaks down in the presence of a money premium. If investors are willing to pay a money premium for money-like claims, above and beyond any risk premia they charge, then by issuing money-like claims, the banking sector can capture the money premium without bearing any additional risk. This ability to earn a riskless profit breaks the Modigliani-Miller argument.

${ }^{16}$ The positive relationship for long maturities shows that $\mathrm{ABCP}$ issuers not only increase their total issuance in response to money demand; they also rotate the composition of their liabilities.
} 
The second column adds year-month fixed effects, and the third column adds week-of-year effects. The relationship remains negative and significant, indicating that it is not driven by low-frequency trends or predictable weekly patterns. The final three columns repeat the exercise, excluding weeks when the Federal Reserve Open Market Committee (FOMC) makes a policy announcement. This demonstrates that the results are not driven by the implementation of changes in the Federal Reserve's policy stance. Note that because I have already demonstrated that $\mathrm{ABCP}$ and T-bills are substitutes, these results suggest that the demand for $\mathrm{ABCP}$ is linked to the demand for reserves, even though no price information from the $\mathrm{ABCP}$ market is being used.

Again, the magnitude of the coefficients is economically plausible. A 1\% lower T-bill yield leads to a $\$ 15-30$ billion larger reserve injection, relative to a mean injection of $\$ 35$ billion and a standard deviation of $\$ 16$ billion.

Panel B of Table 5 examines a prediction of the money demand story that does not come directly from the model. When the Federal Reserve conducted open market operations in the pre-crisis period, it accepted three types of collateral: Treasuries, the debt of the Government Sponsored Enterprises (GSEs), and mortgage-backed securities (MBS) guaranteed by the GSEs. A natural prediction of the money demand story is that when money demand is high the banking sector would like to obtain additional reserves using the least money-like collateral, thus maximizing the net creation of money services. In particular, the fraction of reserve injections collateralized by Treasuries should decrease, assuming that Treasuries provide more money services than GSE debt and MBS. I examine this prediction by running the specification

$$
\text { \%nonTREASURY_COLLATERAL } L_{t}=\alpha+\beta \cdot T \text {-bill }-O I S_{t-1}+\varepsilon_{t} .
$$

The coefficients here are negative and significant, as predicted by the model. A $1 \%$ decrease in T-bill yields results in a 10\% or larger increase in the use of non-Treasury collateral. These results are consistent with the idea that new reserves are created with the least money-like collateral when money demand is high (i.e., when T-bill yields are low). ${ }^{17}$

\footnotetext{
${ }^{17}$ An alternative interpretation of the results is that they simply reflect variation in Treasury supply rather than money demand. It could just be that the T-bill yield is low when the supply of Treasuries is low, and use
} 


\subsubsection{Federal Funds Rate Rises as T-bill Yields Fall}

I now turn to Prediction 5: deviations of the prevailing federal funds rate from the target rate should be negatively correlated with the T-bill - OIS spread. Prior to the reserve supply response of the Federal Reserve, an increase in money demand should increase demand for reserves, driving up the federal funds rate. At the same time, the T-bill yield should fall, because investors highly value the money services offered by Treasury bills. Of course, in the model, the Federal Reserve anticipates changes in money demand, so the prevailing federal funds rate is always pegged to the target. However, if the increase in money demand were unanticipated by the Federal Reserve, one would obtain this prediction.

Table 6 examines the prediction, running the regression:

$$
\Delta T \text {-bill }-O I S_{t}=\alpha+\beta \cdot \Delta\left(F E D F U N D S_{t}-T A R G E T_{t}\right)+\varepsilon_{t} .
$$

The first four columns run the regression at a weekly frequency. The first column shows the raw relationship, while the second column restricts the sample to weeks when the Federal Reserve Open Market Committee does not make a policy announcement. The third column adds year-month fixed effects. The coefficients are negative but typically not statistically significant. This is not surprising. At a weekly frequency, the Federal Reserve has time to push the prevailing federal funds rate back to its target by adjusting the supply of reserves in response to unanticipated money demand shocks.

The next four columns of the table run the same regressions at a daily frequency. Here, the evidence is more consistent. Days when the federal funds rate rises relative to its target are days when the T-bill - OIS spread falls. Note that because I have already demonstrated that $\mathrm{ABCP}$ and T-bills are substitutes, the results in Panel B suggest that the demand for $\mathrm{ABCP}$ is linked to the demand for reserves, even though no price information from the ABCP market is being used.

of non-Treasury collateral is high when the supply of Treasuries is low. However, in untabulated results, we find that the effect remains if we control for the supply of Treasury bills outstanding, though the statistical significance is sometimes weaker. 


\subsubsection{Other Money Quantities Decrease with Spreads}

The empirics up to this point have documented interlinkages between markets for the three claims in the model: Treasury bills, central bank reserves, and ABCP. I can also ask whether low T-bill - OIS spreads are in fact a proxy for high money demand by examining other markets for money-like claims. Increases in demand should raise prices and quantities. If low spreads are indeed a proxy for high money demand, they should be correlated with high quantities of money-like claims beyond those explicitly modeled above. Table 7 examines this prediction directly by looking at contemporaneous relationships between spreads and quantities of money-like claims. I run regressions of the form

$$
\ln \left(M_{t}\right)=\alpha+\beta \cdot T \text {-bill }-O I S_{t}+\varepsilon_{t},
$$

where $M_{t}$ is some measure of the quantity of money. Each column in the table examines a different measure of the quantity of money.

The first column uses the quantity of reserves in the banking sector as a proxy for $M_{t}$. There is a negative and significant relationship, which is not surprising given the results in Table 5. In the second column, the quantity of deposits in the banking sector is negatively, but not significantly, related to the spread. The third and fourth columns show that the assets under management of money market mutual funds are negatively but insignificantly correlated with the spread. The fifth column shows that the size of the money supply, as measured by M2, is negatively and significantly associated with the spread.

Finally, the sixth column examines a different type of proxy: the dollar volume transactions going over the Fedwire Funds payment system. Fedwire is used for payments and clearing services between financial institutions. To the extent that these transactions are driven by transactions in the real economy, this transaction volume reflects money demand. The data are only available monthly, so I cannot use year-month fixed effects as in the other specifications; instead I use year-quarter fixed effects. The results show that Fedwire transaction volume is negatively and significantly correlated with spreads, consistent with the money demand view.

Overall, there is suggestive evidence that some monetary quantities are negatively corre- 
lated with spreads. This is consistent with the money demand story and the use of spreads to proxy for demand at high frequencies.

\subsubsection{Other Corroborating Evidence}

In this section, I briefly discuss other results consistent with the idea that the shadow banking system responds to money demand. First, Table 8 examines the response to money demand shocks of other issuers of short-term debt. Table 8 Panel A examines the behavior of the primary dealers, another channel through which the shadow banking system can respond to money demand shocks. In particular, the liabilities of the primary dealers may provide more money services than some securities and less money services than others. Thus, when money demand is high, the dealers should reduce their positions in securities that provide a lot of money services and increase their positions in securities that provide few money services. Concretely, if the short-term debt of a primary dealer is more money-like than corporate bonds but less money-like than Treasury bills, I should expect dealers to increase their holdings of corporate bonds and decrease their holdings of bills when money demand is high.

Table 8 Panel A examines this prediction. I run regressions of the aggregate net position (long minus short) of the primary dealers in a given security type on the T-bill - OIS spread. Column 1 examines dealer positions in Treasury bills. The coefficient is positive and significant. When money demand is high, T-bill yields are low, and the dealers hold few T-bills,

supplying more to the market. When money demand is low, T-bill yields are high, and the dealers hold more T-bills. Column 2 controls for T-bills outstanding to rule out alternative explanations based on variation in the supply of Treasury bills. The remaining columns show that dealer positions in all Treasury securities and GSE debt decrease when T-bill yields are low. In contrast, net positions in GSE-guaranteed MBS and corporate securities increase when T-bill yields are low. This is consistent with the money demand story. Treasuries and GSE debt provide more money services than the liabilities of the primary dealers. Therefore, when money demand is high, the dealers hold less of these securities. In contrast, MBS and corporate securities provide less money services than the liabilities of the primary dealers. 
Thus, when money demand is high, the dealers hold more of these securities. ${ }^{18}$

Table 8 Panel B analyzes the behavior of commercial paper that is not asset-backed, which is comprised of unsecured commercial paper issued by financial and non-financial firms. Specifically, Table 8 Panel B regresses the log net issuance of unsecured commercial paper on the T-bill - OIS spread. Consistent with the idea that other issuers also react to money demand, the table shows that low T-bill yields forecast the issuance of unsecured commercial paper. The effects are not as strong as those documented for ABCP in Table 2 Panel A, consistent with the idea that the elasticity of ABCP supply is high because securitization provides a large supply of assets that can be used to collateralize ABCP, an idea which is discussed further below.

In addition, the Internet Appendix presents another set of results consistent with the idea that the shadow banking system responds to money demand. The first set shows that money market spreads are highly correlated with each other but not with movements in longer-maturity yields or stock market returns. This is consistent with the money demand story. In the model, the level of money demand $\theta$ should drive the spreads of all money-like claims, but is not strongly linked to broader market conditions at high frequencies.

\section{Discussion}

\subsection{Cumulating the Demand-Side Evidence}

To summarize, the empirical results provide strong evidence in favor of the model presented in Section 2, where variation in the demand for money services plays an important role in driving ABCP issuance. Tables 2 and 3 show that ABCP and T-bills are partial substitutes: increased demand for ABCP and T-bills leads to higher prices and quantities. Tables 47 explicitly link the demand for ABCP and T-bills to the demand for monetary services, demonstrating that the demand for these claims is high at the same time that demand for

\footnotetext{
${ }^{18} \mathrm{An}$ alternative explanation for these results is that the primary dealers are simply engaging in a carry trade, buying longer-term and riskier securities when short-term yields are low. Note that the table controls for the term spread and the Baa-Aaa spread. This helps to rule out this alternative. The results cannot be explained by a story where the dealers simply hold MBS and corporate bonds when the term spread or credit spreads are high.
} 
liquidity and central bank reserves is high.

I now briefly discuss what the high-frequency estimates imply about the low-frequency growth of $\mathrm{ABCP}$ in the years before the crisis. Figure 1 shows the growth of $\mathrm{ABCP}$ over the sample period, which is concentrated from mid-2004 to mid-2007. ABCP outstanding grew 8\% from January 2001-June 2004 and 70\% from June 2004-July 2007.

Extrapolating from Table 2 Panel A, I can try to assess how much of this growth is related to the demand for money-like claims. Specifically, I can compare spreads from June 2004July 2007 relative to January 2001-June 2004, asking whether the results in Table 2 Panel A would predict higher issuance. Many caveats are in order in interpreting such a calculation. First, throughout the paper I take no stand on the sources of demand, which are critical for understanding the welfare implications of the growth of shadow banking. Moreover, without a view on its sources, it is difficult to assess the plausibility of the idea that the demand for money-like claims significantly increased in the mid-2000s. ${ }^{19}$ Second, there are external validity concerns. The results are based on high-frequency variation that I argue is ascribable to changes in demand. It is not clear that these results can be extrapolated to thinking about the low-frequency growth of short-term funding in the shadow banking system before the financial crisis. Put differently, I am measuring short-term elasticities, which may differ from long-term elasticities.

With these caveats in mind, I do the calculation using the estimates in Panel A of Table 2, which relate net $\mathrm{ABCP}$ issuance to spreads. Note that Table 2 is estimated over the entire sample period, January 2001-July 2007. If the sample is restricted to January 2001-June 2004, the results are statistically similar and a bit larger in magnitude. Consistent with the idea that the demand for money-like claims increased in the mid-2000s, the T-bill - OIS spread was 26 bps lower on average from June 2004-July 2007 than it was from January 2001June 2004. The results in Table 2 suggest that these lower spreads translate into roughly $30 \%$ (percentage points) more total ABCP issuance over the latter period than over the early

\footnotetext{
${ }^{19}$ In many narratives emphasizing the demand for money-like claims, the financial sector itself plays an important role. For instance, when securities lenders lend out securities to short sellers, they receive cash as collateral in case the short seller defaults on the loan. They typically invest this cash in money-like claims because it has to be returned to the short seller immediately whenever the short seller chooses to close the position. Securities lending grew rapidly in the mid-2000s, securities lenders held significant quantities of ABCP (Krishnamurthy, Nagel, and Orlov, 2013).
} 
period, or approximately $50 \%$ of the overall increase in ABCP outstanding.

\subsection{The Role of Elastic Supply}

Thus, the high-frequency estimates are consistent with the idea that increased demand for money-like claims played an important role in the growth of shadow banking in the mid2000s. For a shift in demand to create the very large change in quantities observed during that period, it must be the case that the elasticity of ABCP supply is high. The model suggests one way that the elasticity of supply manifests itself in the data: how strongly the banking system responds to increases in the federal funds rate.

Proposition 5 Suppose the Federal Reserve wishes to increase its policy rate $i$. It does so by reducing the supply of reserves so that $\partial \mathcal{R}^{*} / \partial i<0$. The banking system reacts by increasing the supply of $A B C P$ so that $\partial m_{A B C P} / \partial i>0$. When deposits and $A B C P$ are nearly perfect substitutes, $\partial m_{A B C P} / \partial i \approx \rho \alpha_{A B C P} / c^{\prime \prime}$, where $c(\cdot)$ is the cost of manufacturing $A B C P$. In this case, $\partial m_{A B C P} / \partial i$ effectively reveals the elasticity of supply.

The intuition is as follows. The need to hold reserves is effectively a tax banks pay when they issue deposits. When the Federal Reserve increases the federal funds rate, it increases this tax. This causes the banking system to substitute towards ABCP financing. The degree to which it does so is related to the elasticity of ABCP supply, which is captured by $c^{\prime \prime}$, where $c(\cdot)$ is the cost of manufacturing ABCP. When $c^{\prime \prime}$ is low, the marginal costs of ABCP production increase slowly, so supply is more elastic and the banking system substitutes more heavily towards ABCP.

Has the elasticity of supply changed over time? To explore this, Figure 5 examines the relationship between commercial paper outstanding and the federal funds rate over a longer period using rolling regressions with data from the Flow of Funds. At each date $t$, I run a regression of the change in commercial paper outstanding normalized by GDP on the change in the federal funds rate over the 5 years following $t$ and plot the coefficient from that regression. As seen in Figure 5, the relationship has strengthened considerably over the last twenty years, suggesting supply is substantially more elastic than it used to be. 
This evidence is consistent with the idea that the growth of securitization likely played an important role in changing the elasticity of ABCP supply. Estimates of the total stock of securitized bonds before the financial crisis range from $\$ 5-\$ 10$ trillion (Gorton and Metrick, 2010a). By providing a large, elastic supply of assets that could collateralize ABCP, securitization could have significantly increased the elasticity of ABCP supply. ${ }^{20}$

\subsection{The Crisis}

The focus of the paper is the growth of the shadow banking system in the years before the 2007-2009 financial crisis. However, it is worth noting that the money demand narrative is in broad strokes consistent with the collapse of shadow banking during the crisis as well. In particular, one can interpret the onset of the crisis as a decrease in the money services offered by $\mathrm{ABCP}$ and other shadow bank debt. In the model presented above, a sudden reduction in $\alpha_{A B C P}$ would decrease the total quantity of money services available $M$ and thus increase money premia because demand for money services is downward sloping. This would be associated with falling yields on Treasury bills and deposits. In addition, the demand for reserves would rise as banks wished to issue more deposits. To keep the funds rate at its target, the Federal Reserve would have to increase the supply of reserves. This is precisely what happened in August 2007, as the market for ABCP collapsed. ${ }^{21}$

\footnotetext{
${ }^{20}$ The evidence is also consistent with the idea that neglected risks played an important role in the boom, as argued by Gennaioli, Shleifer, and Vishny $(2011,2012)$. In the model, we assumed the amount of money services provided by ABCP, $\alpha_{A B C P}$, did not vary with the quantity of ABCP produced. However, it would be reasonable to think that $\alpha_{A B C P}$ should decline with the quantity of ABCP produced because, for instance, larger quantities of ABCP must be backed by riskier assets. To the extent that this is the case, it is partially captured by the assumption that $c^{\prime \prime}$ is positive. Assuming that banks face constant benefits and increasing marginal costs of ABCP production has similar implications to assuming they have decreasing marginal benefits and fixed marginal costs. Thus, finding a decline in $c^{\prime \prime}$, as Figure 5 suggests, is consistent with the notion that investors began to think the banking system could produce more and more ABCP without sacrificing asset quality. The key question under this interpretation is why investor perceptions changed beginning in the 1990s.

${ }^{21}$ See, for instance, http://www.frbsf.org/education/publications/doctor-econ/2007/august/temporaryreserves-liquidity-injection.
} 


\section{Conclusion}

The growth of the shadow banking system is important to understand, both because of the role it played in the financial crisis and because it sheds light on the role of financial innovation more broadly. A growing literature has emphasized increasing demand for money-like claims as an explanation for the rise of shadow banking. This literature argues that investor demand for money-like claims drove the financial system to manufacture large amounts of short-term debt, specifically ABCP and repo, in the years before the financial crisis.

Despite the prominence of the money demand narrative, its basic premise remains untested. Did the short-term claims issued by the shadow banking system provide money services before the crisis? This paper empirically assesses this question by documenting a novel set of tight interconnections between the markets for Treasury bills, central bank reserves, and short-term shadow bank debt. Examining the pre-crisis period from July 2001 through June 2007, I show that the financial system responds to shocks to the demand for money-like claims, suggesting that money demand played a significant role in driving the growth of shadow banking. 


\section{References}

Baumol, W., 1952. The transactions demand for cash: an inventory theoretic approach. The Quarterly Journal of Economics 66: 545-556.

Bessembinder, H., Maxwell, W., Venkataraman, K., 2013. Introducing daylight to structured credit products. Financial Analyst Journal, forthcoming.

Brunnermeier, M., 2009. Deciphering the 2007-08 liquidity and credit crunch. Journal of Economic Perspectives 23: 77-100.

Carpenter, S., Demiralp, S., 2006. The Liquidity Effect in the Federal Funds Market: Evidence from Daily Open Market Operations. Journal of Money, Credit, and Banking, 38.4: 900-920.

Cochrane, J., 1989. The return of the liquidity effect: a study of the short-run relation between money growth and interest rates. Journal of Business and Economic Statistics 7: 75-83.

Covitz, D., Downing, C., 2007. Liquidity or credit risk? The determinants of very short-term corporate yield spreads. Journal of Finance 62: 2303-2328.

Covitz, D., Liang, N., Suarez, G., 2013. The evolution of a financial crisis: collapse of the assetbacked commercial paper market. Journal of Finance 68: 815-848.

Dang, T., Gorton, G., Holmstrom, B., 2010. Opacity and the optimality of debt for liquidity provision. Unpublished working paper. Yale University.

Diamond, D., Dybvig, P., 1983. Bank runs, deposit insurance, and liquidity. Journal of Political Economy 91: 401-419.

Duffee, G., 1996. Idiosyncratic variation of treasury bill yields. Journal of Finance 51: 527-551.

Duffie, D., Choudhry, M., 2011. Debt markets. Mimeo.

Faig, M., 1989. Seasonal fluctuations and the demand for money. Quarterly Journal of Economics 104: $847-861$.

Federal Reserve Board of Governors, 2005. The Federal Reserve System: Purposes \& Functions. 
Feldhütter, P., Lando, D., 2008. Decomposing swap spreads. Journal of Financial Economics 88: $375-405$.

Gennaioli, N., Shleifer, A., Vishny, R., 2011. A model of shadow banking. Journal of Finance, forthcoming.

Gennaioli, N., Shleifer, A., Vishny, R., 2012. Neglected risks, financial innovation, and financial fragility. Journal of Financial Economics 104: 452-468.

Gorton, G., Lewellen, S., Metrick, A., 2012. The safe asset share. American Economic Review, Papers and Proceedings 102: 101-106.

Gorton, G., Metrick, A., 2011. Securitized banking and the run on repo. Journal of Financial Economics 104: 425-451.

Gorton, G., Metrick, A., 2010a. Haircuts. Federal Reserve Bank of St. Louis Review 92: 507-519.

Gorton, G., Metrick, A., 2010b. Regulating the shadow banking system. Brookings Papers on Economic Activity 41: 261-312.

Gorton, G., Pennacchi, G., 1990. Financial intermediaries and liquidity creation. The Journal of Finance 45: 49-71.

Greenwood, R., Hanson, S., Stein, J., 2013. A comparative-advantage approach to government debt maturity. Unpublished working paper. Harvard University.

Gurkaynak, R., Sack, B., Wright, J., 2007. The U.S. Treasury yield curve: 1961 to the present. Journal of Monetary Economics 54: 2291-2304.

Hamilton, J., 1996. The daily market for federal funds. Journal of Political Economy 104: 26-56.

Hamilton, J., 1997. The supply and demand for Federal Reserve deposits. Carnegie-Rochester Conference on Public Policy discussion paper.

Hamilton, J., 1997. Measuring the liquidity effect. The American Economic Review 87: 80-97.

Ho, T., Saunders, A., 1984. A micro model of the federal funds market. The Journal of Finance 40: 977-988. 
Krishnamurthy, A., Nagel, S., Orlov, D., 2012. Sizing up repo. Working Paper. NBER.

Krishnamurthy, A., Vissing-Jorgensen, A., 2012. The aggregate demand for Treasury debt. Journal of Political Economy 120: 233-267.

Krishnamurthy, A., Vissing-Jorgensen, A., 2013. What drives short-term debt creation? The impact of Treasury supply. Unpublished working paper.

Nagel, S., 2014. The liquidity premium on near-money assets. Working paper, University of Michigan.

Poole, W., 1968. Commercial bank reserve management in a stochastic model: implications for monetary policy. The Journal of Finance 23: 769-791.

Poole, W., Lieberman, C., 1972. Improving Monetary Control. Brookings Papers on Economic Activity, 2: 293-335.

Schwarz, K., 2010. Mind the gap: disentangling credit and liquidity in risk spreads. Unpublished working paper. University of Pennsylvania.

Sidrauski, M., 1967. Rational choice and patterns of growth in a monetary economy. American Economic Review 57: 534-544.

Stein, J., 2012. Monetary policy as financial-stability regulation. Quarterly Journal of Economics 127: 57-95.

Taylor, J.B., 1993. Discretion versus policy rules in practice. Carnegie-Rochester Conference Series on Public Policy 39: 195-214.

Tobin, J., 1956. The interest-elasticity of transactions demand for cash. The Review of Economics and Statistics 38: 241-247.

Tobin, J., Brainard, W., 1963. Financial intermediaries and the effectiveness of monetary controls. The American Economic Review 53: 383-400. 


\section{A Proofs of Propositions}

\section{A.1 Proof of Proposition 1}

Banks solve

$\max _{\widehat{r}, \widehat{m_{D}}, m_{\widehat{A B C} P}} F(1-\widehat{r})-R+\widehat{m_{D}} \theta v^{\prime}(M)\left(\frac{M}{m_{D}}\right)^{1 / \sigma}+m_{A B C P} \alpha_{A B C P} \theta v^{\prime}(M)\left(\frac{M}{m_{A B C P}}\right)^{1 / \sigma}-c\left(m_{A B C P}\right)-\widehat{r i}$

subject to the constraints

$$
\widehat{r}=r^{*}\left(\widehat{m_{D}}\right) \quad \text { and } \widehat{m_{D}}+\widehat{m_{A B C P}} \leq 1
$$

The Lagrangian for this problem is

$$
\begin{aligned}
& F\left(1-r^{*}\left(\widehat{m_{D}}\right)\right)-R+\widehat{m_{D}} \theta v^{\prime}(M)\left(\frac{M}{m_{D}}\right)^{1 / \sigma}+\widehat{m_{A B C P}} \alpha_{A B C P} \theta v^{\prime}(M)\left(\frac{M}{m_{A B C P}}\right)^{1 / \sigma}-c\left(m_{A}\right. \\
&-r^{*}\left(\widehat{m_{D}}\right) \widehat{i} \quad+\lambda\left(1-\widehat{m_{D}}-m_{\widehat{A B C} P}\right) .
\end{aligned}
$$

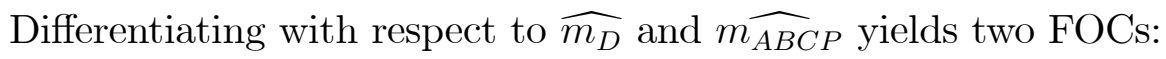

$$
\begin{aligned}
&(-F-\widehat{i}) r^{* \prime}\left(\widehat{m_{D}}\right)\left(\frac{M}{m_{D}}\right)^{1 / \sigma}+\theta v^{\prime}(M)\left(\frac{M}{m_{A B C P}}\right)^{1 / \sigma}-\lambda=0 \\
& \alpha_{A B C P} \theta v^{\prime}(M)-c^{\prime}\left(\widehat{m_{A B C P}}\right)\left(\frac{M}{m_{A B C P}}\right)^{1 / \sigma}-\lambda=0 .
\end{aligned}
$$

First note that the $\lambda$ is the shadow cost of the adding up constraint for the bank's liabilities:

$$
\lambda=\alpha_{A B C P} \theta v^{\prime}(M)\left(\frac{M}{m_{A B C P}}\right)^{1 / \sigma}-c^{\prime}\left(\widehat{m_{A B C P}}\right) .
$$

If $\lambda>0$, the bank would be able to increase profits by using more ABCP funding, except that it is already financing $100 \%$ of its investment using $\mathrm{ABCP}$ and deposits. For a large enough value of $c^{\prime}$, I will be at an interior solution and the constraint is slack. Thus, for a sufficiently large $c^{\prime}$ I can take $\lambda=0$.

In equilibrium, I have market clearing for reserves with identical banks so

$$
\widehat{m_{D}}=r^{*-1}(\mathcal{R})
$$

and

$$
\alpha_{A B C P} \theta v^{\prime}\left(\left(r^{*-1}(\mathcal{R})^{\frac{\sigma-1}{\sigma}}+\alpha_{T} m_{T}^{\frac{\sigma-1}{\sigma}}+\alpha_{A B C P} m_{A B C P}^{\frac{\sigma-1}{\sigma}}\right)^{\frac{\sigma}{\sigma-1}}\right)\left(\frac{M}{m_{A B C P}}\right)^{1 / \sigma}=c^{\prime}\left(m_{A B C P}\right) .
$$

(assuming $c^{\prime}>\underline{c}$ ). These two conditions pin down $\widehat{m_{D}}$ and $\widehat{m_{A B C}}$.

Finally, I can implicitly define the quantity reserves $\mathcal{R}^{*}(i)$ that implements the federal 
funds rate $\widehat{i}=i$ as

$$
F+i=\frac{\theta v^{\prime}\left(\left(r^{*-1}\left(\mathcal{R}^{*}(i)\right)^{\frac{\sigma-1}{\sigma}}+\alpha_{T} m_{T}^{\frac{\sigma-1}{\sigma}}+\alpha_{A B C P} m_{A B C P}^{\frac{\sigma-1}{\sigma}}\right)^{\frac{\sigma}{\sigma-1}}\right)}{r^{* \prime}\left(r^{*-1}\left(\mathcal{R}^{*}(i)\right)\right)} .
$$

\section{A.2 Proof of Proposition 2}

The following expressions will be useful in deriving the comparative statics:

$$
\begin{gathered}
\frac{\partial M}{\partial \theta}=\left(\frac{M}{m_{D}}\right)^{1 / \sigma} \frac{\partial m_{D}}{\partial \theta}+\left(\frac{M}{m_{A B C P}}\right)^{1 / \sigma} \frac{\partial m_{A B C P}}{\partial \theta} \\
\frac{\partial}{\partial \theta}\left(\frac{M}{m_{A B C P}}\right)^{1 / \sigma}=\frac{1}{\sigma}\left(\frac{M}{m_{A B C P}}\right)^{1 / \sigma}\left(\frac{1}{M} \frac{\partial M}{\partial \theta}-\frac{1}{m_{A B C P}} \frac{\partial m_{A B C P}}{\partial \theta}\right),
\end{gathered}
$$

and

$$
\frac{\partial}{\partial \theta}\left(\frac{M}{m_{D}}\right)^{1 / \sigma}=\frac{1}{\sigma}\left(\frac{M}{m_{D}}\right)^{1 / \sigma}\left(\frac{1}{M} \frac{\partial M}{\partial \theta}-\frac{1}{m_{D}} \frac{\partial m_{D}}{\partial \theta}\right) .
$$

Differentiating the first order condition (8) with respect to $\theta$ yields

$$
\begin{aligned}
c^{\prime \prime}\left(\widehat{m_{A B C P}}\right) \frac{\partial m_{A B C P}}{\partial \theta}= & \alpha_{A B C P} v^{\prime}(M)\left(\frac{M}{m_{A B C P}}\right)^{1 / \sigma}+\alpha_{A B C P} \theta v^{\prime \prime}(M) \frac{\partial M}{\partial \theta}\left(\frac{M}{m_{A B C P}}\right)^{1 / \sigma} \\
& +\alpha_{A B C P} v^{\prime}(M) \frac{1}{\sigma}\left(\frac{M}{m_{A B C P}}\right)^{1 / \sigma}\left(\frac{1}{M} \frac{\partial M}{\partial \theta}-\frac{1}{m_{A B C P}} \frac{\partial m_{A B C P}}{\partial \theta}\right)
\end{aligned}
$$

Rearranging I have

$$
\frac{\partial m_{A B C P}}{\partial \theta}=\frac{1}{D}\left[\begin{array}{c}
\alpha_{A B C P} \theta v^{\prime \prime}(M)+ \\
\alpha_{A B C P} \theta v^{\prime}(M) \frac{1}{\sigma M}\left(\frac{M}{m_{D}}\right)^{1 / \sigma}\left(\frac{M}{m_{A B C P}}\right)^{1 / \sigma} \frac{\partial m_{D}}{\partial \theta} \\
+\alpha_{A B C P} v^{\prime}(M)\left(\frac{M}{m_{A B C P}}\right)^{1 / \sigma}
\end{array}\right]
$$

where

$$
\begin{aligned}
D= & c^{\prime \prime}\left(m_{A B C P}\right)-\alpha_{A B C P}^{2} \theta v^{\prime \prime}(M)\left(\frac{M}{m_{A B C P}}\right)^{2 / \sigma} \\
& +\frac{\alpha_{A B C P}}{\sigma} \theta v^{\prime}(M)\left(\frac{M}{m_{A B C P}}\right)^{1 / \sigma}\left(\frac{1}{m_{A B C P}}-\frac{\alpha_{A B C P}}{M}\right)\left(\frac{M}{m_{A B C P}}\right)^{1 / \sigma}
\end{aligned}
$$

A key feature of the equilibrium is that the Federal Reserve will alter the supply of reserves so that the federal funds rate remains at its target, $\hat{i}=i$.Thus, differentiating (11) with respect to $\theta$ yields 


$$
\begin{aligned}
\frac{\partial \hat{i}}{\partial \theta}= & 0=v^{\prime}(M)\left(\frac{M}{m_{D}}\right)^{1 / \sigma}+\theta v^{\prime \prime}(M) \frac{\partial M}{\partial \theta}\left(\frac{M}{m_{D}}\right)^{1 / \sigma} \\
& +\theta v^{\prime}(M) \frac{1}{\sigma}\left(\frac{M}{m_{D}}\right)\left(\frac{1}{M} \frac{\partial M}{\partial \theta}-\frac{1}{m_{D}} \frac{\partial m_{D}}{\partial \theta}\right)
\end{aligned}
$$

Plugging in the expression for $\frac{\partial m \widehat{A B C} P}{\partial \theta}$ yields and simplifying gives

$$
\frac{\partial \widehat{m_{D}}}{\partial \theta}=-\frac{\left(\frac{M}{m_{D}}\right)^{1 / \sigma}\left[c^{\prime \prime}\left(\widehat{m_{A B C P}}\right)+\frac{\alpha_{A B C P}}{\sigma m_{A B C P}}\left(\frac{M}{m_{A B C P}}\right)^{1 / \sigma} v^{\prime}(M)\right] v^{\prime}(M)}{A c^{\prime \prime}\left(\widehat{m_{A B C P}}\right)+\left(B_{1} v^{\prime \prime}(M)+B_{2} v^{\prime}(M)\right) v^{\prime}(M)},
$$

where

$$
\begin{aligned}
A= & \left(\frac{\theta}{\sigma M}\left(\frac{M}{m_{D}}\right)^{2 / \sigma}-\frac{\theta}{\sigma m_{D}}\left(\frac{M}{m_{D}}\right)^{1 / \sigma}\right) v^{\prime}(M)+\theta\left(\frac{M}{m_{D}}\right)^{2 / \sigma} v^{\prime \prime}(M) \\
B_{1}= & \frac{\alpha_{A B C P} \theta^{2}}{\sigma}\left(\frac{M}{m_{D}}\right)^{1 / \sigma}\left(\frac{M}{m_{A B C P}}\right)^{1 / \sigma} \times \\
& {\left[\frac{1}{m_{A B C P}}\left(\frac{M}{m_{D}}\right)^{1 / \sigma}+\frac{\alpha_{A B C P}}{m_{D}}\left(\frac{M}{m_{A B C P}}\right)^{1 / \sigma}+\frac{2 \alpha_{A B C P}}{M}\left(\frac{M}{m_{D}}\right)^{1 / \sigma}\left(\frac{M}{m_{A B C P}}\right)^{1 / \sigma}\right] } \\
B_{2}= & \frac{\alpha_{A B C P} \theta^{2}}{\sigma}\left(\frac{M}{m_{D}}\right)^{1 / \sigma}\left(\frac{M}{m_{A B C P}}\right)^{1 / \sigma} \times \\
& {\left[\frac{1}{m_{A B C P} M}\left(\frac{M}{m_{D}}\right)^{1 / \sigma}+\frac{\alpha_{A B C P}}{m_{D} M}\left(\frac{M}{m_{A B C P}}\right)^{1 / \sigma}-\frac{1}{m_{A B C P} m_{D}}\right] . }
\end{aligned}
$$

The numerator of $\frac{\partial \widehat{m_{D}}}{\partial \theta}$ is negative since $c^{\prime \prime}>0$ and $v^{\prime}>0$. The first term of the denominator $A c^{\prime \prime}\left(m_{A B C P}\right)$ is negative if $\left(M / m_{D}\right)^{1 / \sigma}<M / m_{D}$, which is the case if and only if $\sigma>1$. The second term in the numerator $\left(B_{1} v^{\prime \prime}(M)+B_{2} v^{\prime}(M)\right) v^{\prime}(M)$ is negative since $\sigma>1$ implies that $B_{1}>0$ and $B_{2}<0$. Thus $\sigma>1$ is a sufficient condition for $\frac{\partial \widehat{m_{D}}}{\partial \theta}>0$.

From the market clearing condition for reserves I have $r^{*}\left(\widehat{m_{D}}\right)=\mathcal{R}$, which implies that

$$
r^{* \prime}\left(\widehat{m_{D}}\right) \frac{\partial \widehat{m_{D}}}{\partial \theta}=\frac{\partial \mathcal{R}^{*}}{\partial \theta} .
$$

Since $r^{* \prime}>0$, this implies $\frac{\partial \mathcal{R}^{*}}{\partial \theta}>0$. 
Finally, plugging back into the expression for $\frac{\partial m_{\widehat{A B C} P}}{\partial \theta}$ yields

$$
\begin{aligned}
\frac{\partial m_{A B C P}}{\partial \theta}= & \frac{2\left(\frac{\theta^{2} \alpha_{A B C P}^{3}}{\sigma M}\right)\left(\frac{M}{m_{D}}\right)^{2 / \sigma}\left(\frac{M}{m_{A B C P}}\right)^{3 / \sigma} v^{\prime}(M)^{2} v^{\prime \prime}(M)}{D\left[A c^{\prime \prime}\left(m_{A B C P}\right)+\left(B_{1} v^{\prime \prime}(M)+B_{2} v^{\prime}(M)\right) v^{\prime}(M)\right]} \\
& -\frac{\frac{\alpha_{A B C P} \theta}{\sigma m_{D}}\left(\frac{M}{m_{A B C P}}\right)^{1 / \sigma}\left(\frac{M}{m_{D}}\right)^{1 / \sigma} v^{\prime}(M)^{2}}{A c^{\prime \prime}\left(m_{A B C P}\right)+\left(B_{1} v^{\prime \prime}(M)+B_{2} v^{\prime}(M)\right) v^{\prime}(M)}
\end{aligned}
$$

The numerator of the first term is negative since $v^{\prime \prime}<0$. The numerator of the second term is negative. The denominators are negative if $\sigma>1$. Thus, if $\sigma>1$ I have $\frac{\partial m_{A B C P}}{\partial \theta}>0$.

\section{A.3 Proof of Proposition 3}

The Treasury bill yield is given by

$$
R_{T}=R-\theta v^{\prime}(M) \alpha_{T}\left(\frac{M}{m_{T}}\right)^{1 / \sigma}
$$

Differentiating with respect to $\theta$ yields

$$
\begin{aligned}
-\frac{\partial R_{T}}{\partial \theta} & =\alpha_{T} v^{\prime}(M)\left(\frac{M}{m_{T}}\right)^{1 / \sigma}+\alpha_{T} \theta v^{\prime \prime}(M)\left(\frac{M}{m_{T}}\right)^{1 / \sigma} \frac{d M}{\partial \theta}+\alpha_{T} \theta v^{\prime}(M) \frac{\partial}{\partial \theta}\left(\frac{M}{m_{T}}\right)^{1 / \sigma} \\
& =\alpha_{T} v^{\prime}(M)\left(\frac{M}{m_{T}}\right)^{1 / \sigma}+\alpha_{T} \theta v^{\prime \prime}(M)\left(\frac{M}{m_{T}}\right)^{1 / \sigma} \frac{d M}{\partial \theta}+\alpha_{T} \theta v^{\prime}(M) \frac{1}{\sigma}\left(\frac{M}{m_{T}}\right)^{1 / \sigma}\left(\frac{1}{M} \frac{\partial M}{\partial \theta}-\frac{1}{m_{T}} \frac{\partial m^{\prime}}{\partial \theta}\right. \\
& =\alpha_{T}\left(\frac{M}{m_{T}}\right)^{1 / \sigma}\left(v^{\prime}(M)+\theta v^{\prime \prime}(M) \frac{d M}{\partial \theta}+\frac{\theta v^{\prime}(M)}{\sigma M} \frac{\partial M}{\partial \theta}\right)
\end{aligned}
$$

I again use the fact that the Federal Reserve adjusts the quantity of reserves so that the Federal Funds rate remains unchanged. Differentiating (11) with respect to $\theta$ yields

$$
\begin{aligned}
\frac{\partial \hat{i}}{\partial \theta}= & 0=v^{\prime}(M)\left(\frac{M}{m_{D}}\right)^{1 / \sigma}+\theta v^{\prime \prime}(M) \frac{\partial M}{\partial \theta}\left(\frac{M}{m_{D}}\right)^{1 / \sigma} \\
& +\theta v^{\prime}(M) \frac{1}{\sigma}\left(\frac{M}{m_{D}}\right)^{1 / \sigma}\left(\frac{1}{M} \frac{\partial M}{\partial \theta}-\frac{1}{m_{D}} \frac{\partial m_{D}}{\partial \theta}\right)
\end{aligned}
$$

and rearranging gives

$$
v^{\prime}(M)+\theta\left(v^{\prime \prime}(M)+\frac{v^{\prime}(M)}{\sigma M}\right) \frac{\partial M}{\partial \theta}=\frac{\theta v^{\prime}(M)}{\sigma m_{D}} \frac{\partial m_{D}}{\partial \theta} .
$$

Substituting this into the expression for the comparative static I have

$$
\frac{\partial R_{T}}{\partial \theta}=-\alpha_{T} \frac{\theta v^{\prime}(M)}{\sigma m_{D}} \frac{\partial m_{D}}{\partial \theta} .
$$


$\frac{\partial m_{D}}{\partial \theta}$ is positive if $\sigma>1$. The expression is thus negative.

\section{A.4 Proof of Proposition 4}

First note that

$$
\frac{\partial M}{\partial m_{T}}=\left(\frac{M}{m_{D}}\right)^{1 / \sigma} \frac{\partial m_{D}}{\partial m_{T}}+\alpha_{T}\left(\frac{M}{m_{T}}\right)^{1 / \sigma}+\alpha_{A B C P}\left(\frac{M}{m_{A B C P}}\right)^{1 / \sigma} \frac{\partial m_{A B C P}}{\partial m_{T}}
$$

and

$$
\frac{\partial\left(\frac{M}{m_{A B C P}}\right)^{1 / \sigma}}{\partial m_{T}}=\frac{1}{\sigma}\left(\frac{M}{m_{A B C P}}\right)^{1 / \sigma}\left(\frac{1}{M} \frac{\partial M}{\partial m_{T}}-\frac{1}{m_{A B C P}} \frac{\partial m_{A B C P}}{\partial m_{T}}\right) .
$$

Differentiating the first order condition (8) with respect to $m_{T}$ yields

$$
\frac{\partial m_{A B C P}}{\partial m_{T}}=\frac{1}{D}\left[\begin{array}{c}
\left(\alpha_{A B C P} \theta v^{\prime \prime}(M)+\alpha_{A B C P} \theta v^{\prime}(M) \frac{1}{\sigma M}\right)\left(\frac{M}{m_{D}}\right)^{1 / \sigma}\left(\frac{M}{m_{A B C P}}\right)^{1 / \sigma} \frac{\partial m_{D}}{\partial m_{T}} \\
+\alpha_{A B C P} \alpha_{T} \theta\left(\frac{M}{m_{T}}\right)^{1 / \sigma}\left(\frac{M}{m_{A B C P}}\right)^{1 / \sigma}\left(v^{\prime \prime}(M)+\frac{v^{\prime}(M)}{\sigma M}\right)
\end{array}\right]
$$

where $D$ is defined in the proof of proposition 2 above. A critical feature of the equilibrium is that the Federal Reserve will alter the supply of reserves so that the federal funds rate remains at its target, $\widehat{i}=i$. Thus, differentiating (11) with respect to $m_{T}$ yields

$$
\begin{aligned}
\frac{\partial \hat{i}}{\partial m_{T}}= & =\alpha_{T} \theta\left(\frac{M}{m_{T}}\right)^{1 / \sigma}\left(\frac{M}{m_{D}}\right)^{1 / \sigma}\left(v^{\prime \prime}(M)+\frac{v^{\prime}(M)}{\sigma M}\right) \\
+ & {\left[\left(\frac{\theta}{\sigma M}\left(\frac{M}{m_{D}}\right)^{2 / \sigma}-\frac{\theta}{\sigma m_{D}}\left(\frac{M}{m_{D}}\right)^{1 / \sigma}\right) v^{\prime}(M)+\theta\left(\frac{M}{m_{D}}\right)^{2 / \sigma} v^{\prime \prime}(M)\right] \frac{\partial m_{D}}{\partial m_{T}} } \\
& +\left[\theta \alpha_{A B C P}\left(\frac{M}{m_{D}}\right)^{1 / \sigma}\left(\frac{M}{m_{A B C P}}\right)^{1 / \sigma}\left(v^{\prime \prime}(M)+\frac{v^{\prime}(M)}{\sigma M}\right)\right] \frac{\partial m_{A B C P}}{\partial m_{T}} .
\end{aligned}
$$

Substituting for $\frac{\partial m_{A B C P}}{\partial m_{T}}$ and solving for $\frac{\partial m_{D}}{\partial m_{T}} \mathrm{I}$ have

$\frac{\partial m_{D}}{\partial m_{T}}=\frac{\left[\alpha_{T} \theta\left(\frac{M}{m_{T}}\right)^{1 / \sigma}\left(\frac{M}{m_{D}}\right)^{1 / \sigma}\left(v^{\prime \prime}(M)+\frac{v^{\prime}(M)}{\sigma M}\right)\right]\left[c^{\prime \prime}\left(\widehat{m_{A B C P}}\right)+\frac{\alpha_{A B C P} \theta}{\sigma m_{A B C P}}\left(\frac{M}{m_{A B C P}}\right)^{1 / \sigma} v^{\prime}(M)\right]}{A c^{\prime \prime}\left(\widehat{m_{A B C P}}\right)+\left(B_{1} v^{\prime \prime}(M)+B_{2} v^{\prime}(M)\right) v^{\prime}(M)}$.

The denominator is negative if $\sigma>1$. The numerator is negative is $v^{\prime \prime}(M)+\frac{v^{\prime}(M)}{\sigma M}<0$, which will be true if either $\sigma$ or $M$ is sufficiently large. In this case, I have $\frac{\partial m_{D}}{\partial m_{T}}<0$. 
Plugging back into the expression for $\frac{\partial m_{A B C P}}{\partial m_{T}}$ yields

$$
\begin{aligned}
\frac{\partial m_{A B C P}}{\partial m_{T}}= & \frac{C\left[\left(\frac{2 \alpha_{A B C P}^{2} \theta^{2}}{\sigma M}\left(\frac{M}{m_{D}}\right)^{2 / \sigma}\left(\frac{M}{m_{A B C P}}\right)^{2 / \sigma} v^{\prime \prime}(M)-D \frac{\theta}{\sigma m_{D}}\left(\frac{M}{m_{D}}\right)^{1 / \sigma}\right) v^{\prime}(M)\right]}{D\left(A c^{\prime \prime}\left(m_{A B C P}\right)+\left(B_{1} v^{\prime \prime}(M)+B_{2} v^{\prime}(M)\right) v^{\prime}(M)\right)} \\
+ & {\left[\frac{\left.M\left(\left(\frac{M}{m_{D}}\right)^{1 / \sigma}-1\right)\left(\frac{M}{m_{D}}\right)^{1 / \sigma}\right] \times}{D\left(A c^{\prime \prime}\left(m_{\widehat{A B C P}}\right)+\left(B_{1} v^{\prime \prime}(M)+B_{2} v^{\prime}(M)\right) v^{\prime}(M)\right)}\right], }
\end{aligned}
$$

where

$$
C=\alpha_{A B C P} \alpha_{T} \theta\left(\frac{M}{m_{T}}\right)^{1 / \sigma}\left(\frac{M}{m_{A B C P}}\right)^{1 / \sigma}\left(v^{\prime \prime}(M)+\frac{v^{\prime}(M)}{\sigma M}\right) .
$$

If $\sigma>1$, the denominator is negative. And if $v^{\prime \prime}(M)+\frac{v^{\prime}(M)}{\sigma M}<0$, then $C<0$. Thus for $\sigma$ sufficiently large, I have that the overall expression is negative and $\frac{\partial m_{A B C P}}{\partial m_{T}}<0$.

The Treasury bill yield is given by

$$
R_{T}=R-\alpha_{T} \theta v^{\prime}(M)\left(\frac{M}{m_{T}}\right)^{1 / \sigma} .
$$

Differentiating with respect to $m_{T}$ yields

$$
\begin{aligned}
\frac{\partial\left(\frac{M}{m_{A B C P}}\right)^{1 / \sigma}}{\partial m_{T}} & =\frac{1}{\sigma}\left(\frac{M}{m_{A B C P}}\right)^{1 / \sigma}\left(\frac{1}{M} \frac{\partial M}{\partial m_{T}}-\frac{1}{m_{A B C P}} \frac{\partial m_{A B C P}}{\partial m_{T}}\right) \\
\frac{\partial}{\partial m_{T}}\left(\frac{M}{m_{T}}\right)^{1 / \sigma} & =\frac{1}{\sigma}\left(\frac{M}{m_{T}}\right)^{\frac{1-\sigma}{\sigma}}\left(\frac{1}{m_{T}} \frac{\partial M}{\partial m_{T}}-\frac{M}{m_{T}^{2}}\right) \\
& =\frac{1}{\sigma}\left(\frac{M}{m_{T}}\right)^{\frac{1}{\sigma}}\left(\frac{1}{M} \frac{\partial M}{\partial m_{T}}-\frac{1}{m_{T}}\right) \\
-\frac{\partial R_{T}}{\partial m_{T}}=\alpha_{T} \theta v^{\prime \prime}(M)\left(\frac{M}{m_{T}}\right)^{1 / \sigma} \frac{\partial M}{\partial m_{T}}+\alpha_{T} \theta v^{\prime}(M) \frac{\partial}{\partial m_{T}}\left(\frac{M}{m_{T}}\right)^{1 / \sigma} & \alpha_{T} \theta\left(\frac{M}{m_{T}}\right)^{1 / \sigma}\left(\left(v^{\prime \prime}(M)+\frac{v^{\prime}(M)}{\sigma M}\right) \frac{\partial M}{\partial m_{T}}-\frac{1}{m_{T}} v^{\prime}(M)\right)
\end{aligned}
$$

I can sign $\frac{d M}{\partial m_{T}}$ using the fact that in equilibrium, the federal funds rate is unchanged. I have

$$
\theta\left(v^{\prime \prime}(M)+\frac{v^{\prime}(M)}{\sigma M}\right) \frac{d M}{\partial m_{T}}=\frac{\theta v^{\prime}(M)}{\sigma m_{D}} \frac{d m_{D}}{\partial m_{T}}
$$


which implies

$$
-\frac{\partial R_{T}}{\partial m_{T}}=\alpha_{T} \theta\left(\frac{M}{m_{T}}\right)^{1 / \sigma}\left(\frac{\theta v^{\prime}(M)}{\sigma m_{D}} \frac{d m_{D}}{\partial m_{T}}-\frac{1}{m_{T}} v^{\prime}(M)\right)
$$

Thus, when $\frac{d m_{D}}{\partial m_{T}}<0$, I have $\frac{\partial R_{T}}{\partial m_{T}}>0$.

\section{A.5 Proof of Proposition 5}

I prove the proposition by differentiating the first order conditions that define the equilibrium with respect to the target federal funds rate $i$. Differentiating the first order condition (8) with respect to $i$ gives

$$
\alpha_{A B C P} \theta v^{\prime \prime}(M)\left[\frac{1}{r^{* \prime}\left(r^{-1}(\mathcal{R})\right)} \frac{\partial \mathcal{R}^{*}}{\partial i}+\alpha_{A B C P} \frac{\partial m_{A B C P}}{\partial i}\right]=c^{\prime \prime}\left(m_{A B C P}\right) \frac{\partial m_{A B C P}}{\partial i},
$$

and simplifying yields

$$
\frac{\partial m_{A B C P}}{\partial i}=\frac{-\alpha_{A B C P} \theta v^{\prime \prime}(M)}{\alpha_{A B C P}^{2} \theta v^{\prime \prime}(M)-c^{\prime \prime}\left(m_{A B C P}^{*}\right)} \frac{1}{r^{* \prime}\left(r^{-1}(\mathcal{R})\right)} \frac{\partial \mathcal{R}^{*}}{\partial i} .
$$

Differentiating (11) with respect to $i$ yields

$$
r^{* \prime}\left(\widehat{m_{D}}\right)=\theta v^{\prime \prime}(M)\left[\frac{1}{r^{* \prime}\left(r^{-1}(\mathcal{R})\right)} \frac{\partial \mathcal{R}^{*}}{\partial i}+\alpha_{A B C P} \frac{\partial m_{A B C P}}{\partial i}\right]+\frac{1}{r^{* \prime}\left(r^{-1}(\mathcal{R})\right)} \frac{\partial \mathcal{R}^{*}}{\partial i},
$$

and simplifying yields

$$
\begin{aligned}
r^{* \prime}\left(\widehat{m_{D}}\right)= & \theta v^{\prime \prime}(M)\left[\frac{-c^{\prime \prime}\left(m_{A B C P}^{*}\right)}{\alpha_{A B C P}^{2} \theta v^{\prime \prime}(M)-c^{\prime \prime}\left(m_{A B C P}^{*}\right)}\right] \frac{1}{r^{* \prime}\left(r^{-1}(\mathcal{R})\right)} \frac{\partial \mathcal{R}^{*}}{\partial i}+\frac{1}{r^{* \prime}\left(\widehat{m_{D}}\right)} \frac{\partial \mathcal{R}^{*}}{\partial i}, \\
& \frac{1}{r^{* \prime}\left(r^{-1}(\mathcal{R})\right)} \frac{\partial \mathcal{R}^{*}}{\partial i}=r^{* \prime}\left(\widehat{m_{D}}\right)\left[-\frac{c^{\prime \prime}\left(m_{A B C P}^{*}\right) \theta v^{\prime \prime}(M)}{\alpha_{A B C P}^{2} \theta v^{\prime \prime}(M)-c^{\prime \prime}\left(m_{A B C P}^{*}\right)}\right]^{-1} \cdot
\end{aligned}
$$

Since $w^{\prime \prime}<0$, the first term in the square brackets is negative. Since $c^{\prime \prime}>0$ and $v^{\prime \prime}<0$, the numerator of the second term is negative. Since $c^{\prime \prime}>0$ and $v^{\prime \prime}<0$, the denominator of the second term is also negative. Thus, the full term in the square brackets is negative and $\frac{1}{\rho} \frac{\partial \mathcal{R}^{*}}{\partial i}<0$.

Finally, plugging back into the expression for $\frac{\partial m_{\widehat{A B C} P}}{\partial i}$ yields

$$
\frac{\partial m_{A B C P}}{\partial i}=\frac{-\alpha_{A B C P} \theta v^{\prime \prime}(M)}{\alpha_{A B C P}^{2} \theta v^{\prime \prime}(M)-c^{\prime \prime}\left(m_{A B C P}^{*}\right)} r^{* \prime}\left(\widehat{m_{D}}\right)\left[-\frac{c^{\prime \prime}\left(m_{A B C P}^{*}\right) \theta v^{\prime \prime}(M)}{\alpha_{A B C P}^{2} \theta v^{\prime \prime}(M)-c^{\prime \prime}\left(m_{A B C P}^{*}\right)}\right]^{-1} \text {. }
$$

I know that the term in the square brackets is negative. Since $v^{\prime \prime}<0$, the numerator of the term outside the square brackets is positive. Since $c^{\prime \prime}>0$ and $v^{\prime \prime}<0$, the denominator of the term is negative. Thus, the whole expression is positive and $\frac{\partial m_{\overparen{A B C} P}}{\partial i}>0$. 


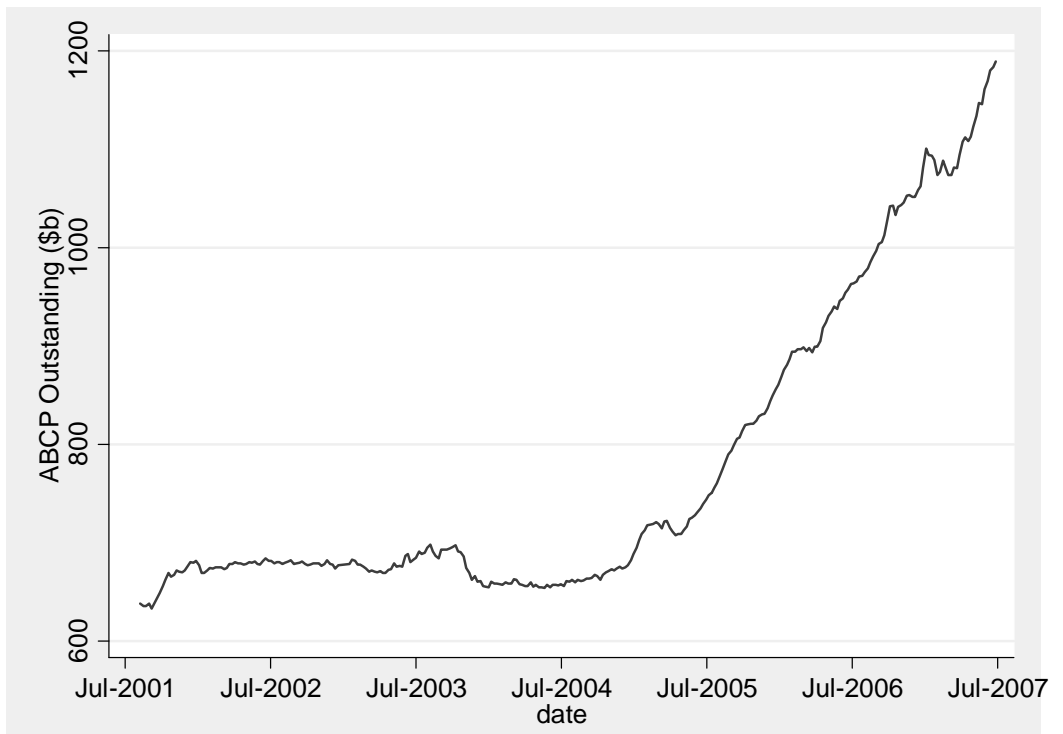

Figure 1

ABCP Outstanding

This figure shows the time series of ABCP outstanding from July 2001-June 2007.

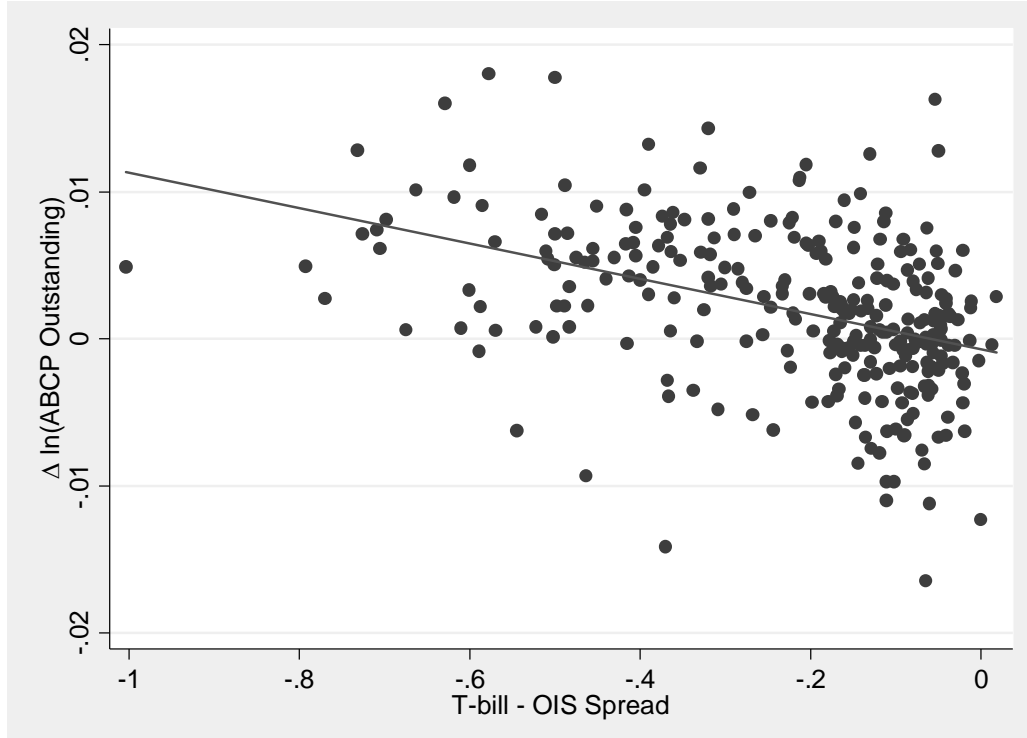

Figure 2

ABCP Issuance and the T-bill - OIS Spread

This figure plots net ABCP issuance against the value of the T-bill - OIS spread from July 2001-June 2007. The red line shows the best linear fit. 


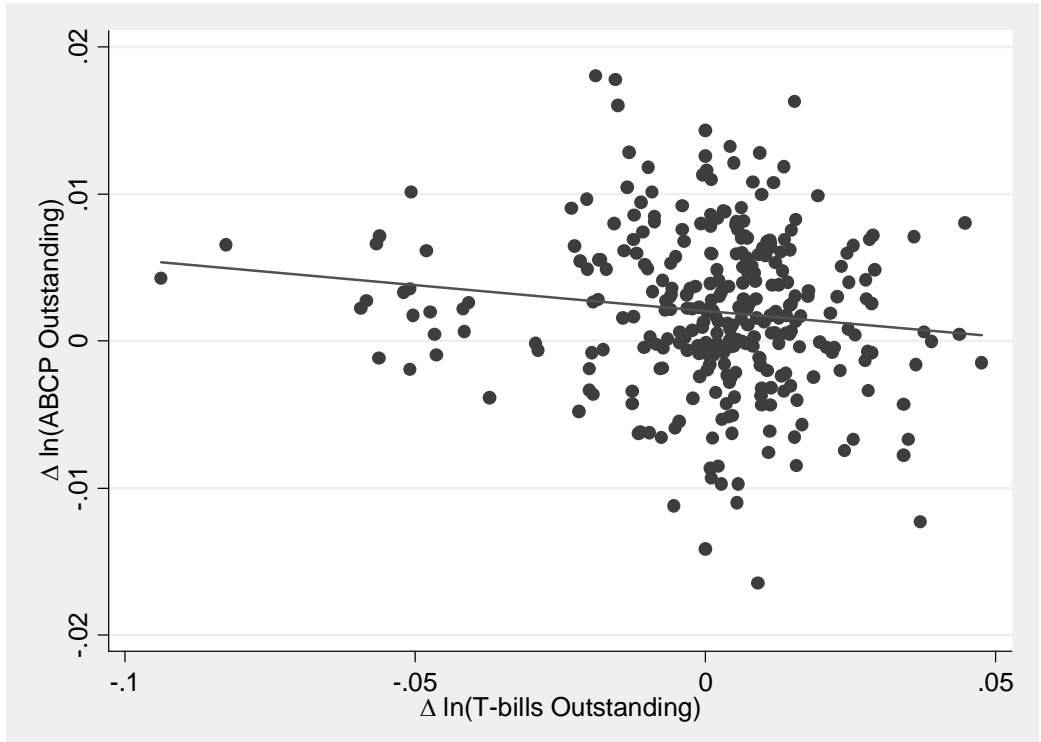

Figure 3

\section{ABCP Issuance and Treasury Bill Issuance}

This figure plots net ABCP issuance against net Treasury bill issuance from July 2001-June 2007. The red line shows the best linear fit.

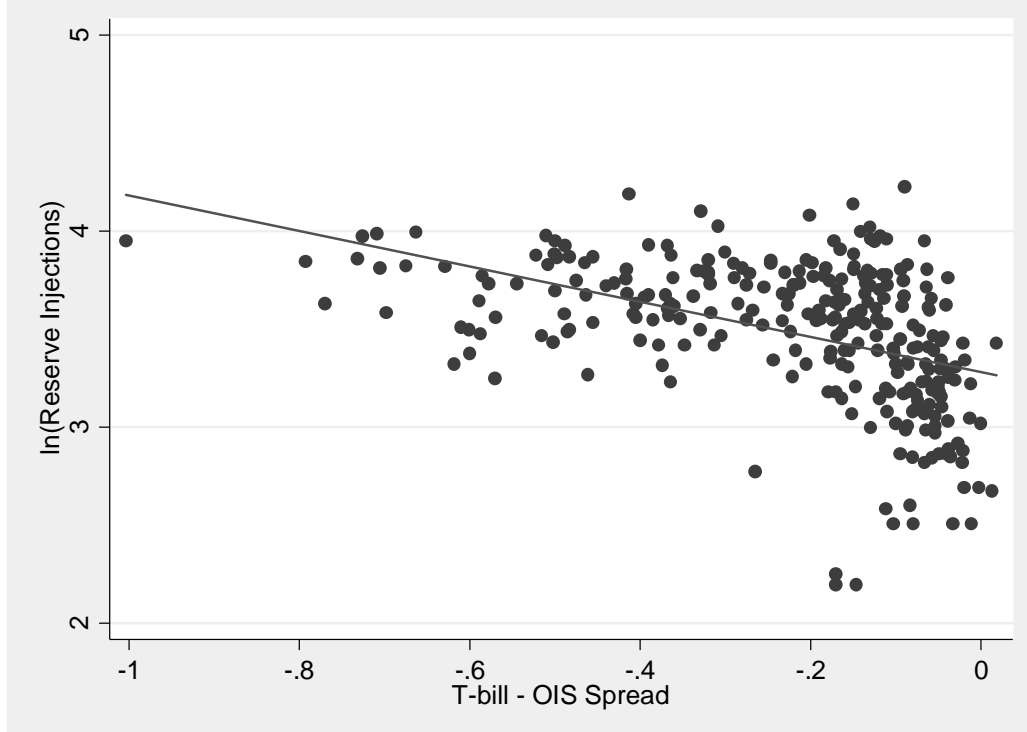

Figure 4

Reserve Injections and the T-bill - OIS Spread

This figure plots temporary reserve injections against the value of the T-bill - OIS spread from July 2001June 2007. The red line shows the best linear fit. 


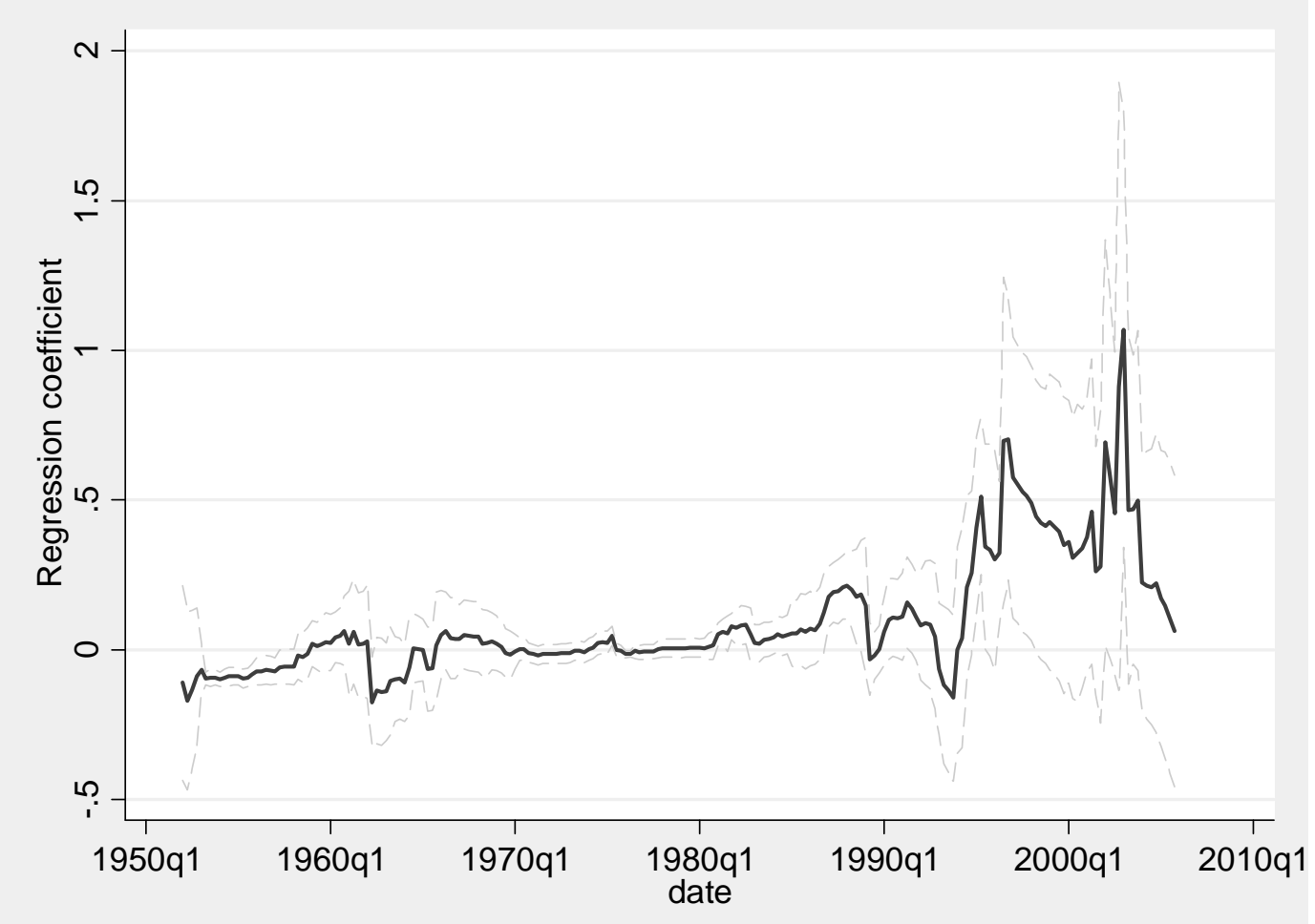

Figure 5

Relationship between CP outstanding and the Federal Funds Rate over Time

This figure reports the coefficients from a rolling regression of commercial paper outstanding on the Federal Funds rate. At each date we run a regression of the change in commercial paper outstanding normalized by GDP on the change in the Federal Funds rate over the following 5 years and plot the coefficient from that regression. Confidence intervals (dotted lines) computed using robust standard errors are reported. 


\section{Table 1 \\ Summary Statistics}

This table presents summary statistics for the variables used in the paper. T-bill - OIS is the spread of 4week Treasury bills over the 4-week overnight indexed swap (OIS) rate; $\ln (\mathrm{ABCP}$ Out) is $\log \mathrm{ABCP}$ outstanding; $\triangle \ln (\mathrm{ABCP}$ Out) is $\log$ net $\mathrm{ABCP}$ issuance; $\ln (\mathrm{T}$-bills Out) is log Treasury bills outstanding; $\Delta \ln$ (T-bills Out) is log net Treasury bill issuance; Reserves Injected is net reserve injections (repo minus reverse repo). The sample runs weekly from July 2001-June 2007.

\begin{tabular}{|c|c|c|c|c|c|}
\hline & $\mathrm{N}$ & Mean & sd & $\min$ & $\max$ \\
\hline T-bill - OIS (\%) & 288 & -0.226 & 0.193 & -1.060 & 0.018 \\
\hline ABCP Outstanding ( $\$ \mathrm{~b})$ & 303 & 776.0 & 153.0 & 633 & 1189 \\
\hline $\ln (\mathrm{ABCP}$ Out $)$ & 303 & 13.54 & 0.180 & 13.36 & 13.99 \\
\hline$\Delta \ln \left(\mathrm{ABCP} \mathrm{Out}_{t-1}\right)$ & 303 & 0.002 & 0.005 & -0.016 & 0.018 \\
\hline T-bills Outstanding (\$b) & 303 & 932.0 & 75.0 & 691 & 1089 \\
\hline $\ln \left(\right.$ T-bills Out $\left.{ }_{t}\right)$ & 303 & 6.834 & 0.084 & 6.538 & 6.993 \\
\hline$\Delta \ln \left(\right.$ T-bills Out $\left.t_{t-1}\right)$ & 303 & 0.001 & 0.020 & -0.094 & 0.048 \\
\hline Reserves Injected (\$b) & 303 & 34.09 & 12.35 & 4.75 & 114.29 \\
\hline $\ln ($ Reserves Injected) & 303 & 3.46 & 0.410 & 1.56 & 4.74 \\
\hline
\end{tabular}


Table 2

ABCP Net Issuance and T-bill Yields

This table shows regressions of the form

$$
\Delta \ln (\text { ABCP OUTSTANDING })=\alpha+\beta \cdot T \text {-bill }- \text { OIS }_{t-1}+\varepsilon_{t} .
$$

T-bill - OIS is the spread of 4-week Treasury bills over the 4-week overnight indexed swap (OIS) rate, Zspread is the spread of 4-week Treasury bills over the yield on 4-week Treasury bills implied by longerterm Treasury yields. $\ln \left(\mathrm{ABCP} \mathrm{Out}_{\mathrm{t}-1}\right)$ is lagged $\log \mathrm{ABCP}$ outstanding, and $\Delta \ln \left(\mathrm{ABCP}_{\mathrm{Out}} \mathrm{A}\right)$ is lagged $\log$ net $\mathrm{ABCP}$ issuance (the lagged change in $\log \mathrm{ABCP}$ outstanding). The sample runs weekly from July 2001-June 2007. YM denotes year-month fixed effects, while WOY denotes week-of-year fixed effects. Robust standard errors are reported in parentheses, except for the specifications without fixed effects which report Newey-West standard errors with 12 lags. In specifications with fixed effects, we report the residual $\mathrm{R}^{2} . *, * * * * *$ denote significance at the $10 \%, 5 \%$, and $1 \%$ levels respectively.

\begin{tabular}{|c|c|c|c|c|c|}
\hline \multirow[b]{2}{*}{ T-bill - OIS $_{t-1}$} & \multicolumn{5}{|c|}{ Panel A: T-bill - OIS Spread } \\
\hline & $\begin{array}{l}-0.012 * * * \\
(0.002)\end{array}$ & $\begin{array}{l}-0.009 * * \\
(0.004)\end{array}$ & $\begin{array}{l}-0.009 * * * \\
(0.002)\end{array}$ & $\begin{array}{l}-0.013 * * * \\
(0.004)\end{array}$ & $\begin{array}{r}-0.012 * * \\
(0.005)\end{array}$ \\
\hline $\ln \left(\mathrm{ABCP}\right.$ Out $\left._{\mathrm{t}-1}\right)$ & & & $\begin{array}{c}0.002 \\
(0.002)\end{array}$ & $\begin{array}{l}-0.359 * * * \\
(0.068)\end{array}$ & $\begin{array}{l}-0.434^{* * *} \\
(0.071)\end{array}$ \\
\hline$\Delta \ln \left(\mathrm{ABCP}\right.$ Out $\left._{t-1}\right)$ & & & $\begin{array}{c}0.125^{*} \\
(0.069)\end{array}$ & $\begin{array}{c}0.014 \\
(0.083)\end{array}$ & $\begin{array}{c}0.091 \\
(0.086)\end{array}$ \\
\hline Constant & $\begin{array}{l}-0.001 \\
(0.000)\end{array}$ & $\begin{array}{l}-0.000 \\
(0.001)\end{array}$ & $\begin{array}{l}-0.022 \\
(0.031)\end{array}$ & $\begin{array}{l}4.862 * * * \\
(0.923)\end{array}$ & $\begin{array}{l}5.919^{* * *} \\
(0.969)\end{array}$ \\
\hline $\mathrm{R}^{2}$ & 0.169 & 0.028 & 0.178 & 0.224 & 0.356 \\
\hline $\mathrm{N}$ & 287 & 287 & 286 & 286 & 286 \\
\hline \multirow[t]{2}{*}{ FE } & --- & YM & --- & YM & YM, WOY \\
\hline & \multicolumn{5}{|c|}{ Panel B: Z-spread } \\
\hline Z-Spread ${ }_{t-1}$ & $\begin{array}{l}-0.009 * * * \\
(0.002)\end{array}$ & $\begin{array}{l}-0.007 * * \\
(0.003)\end{array}$ & $\begin{array}{l}-0.004^{* *} \\
(0.002)\end{array}$ & $\begin{array}{l}-0.009 * * * \\
(0.003)\end{array}$ & $\begin{array}{l}-0.008^{*} \\
(0.004)\end{array}$ \\
\hline $\ln \left(\mathrm{ABCP}\right.$ Out $\left._{t-1}\right)$ & & & $\begin{array}{l}0.005^{* *} \\
(0.002)\end{array}$ & $\begin{array}{l}-0.360 * * * \\
(0.063)\end{array}$ & $\begin{array}{l}-0.435^{* * *} \\
(0.064)\end{array}$ \\
\hline$\Delta \ln \left(\mathrm{ABCP}\right.$ Out $\left._{t-1}\right)$ & & & $\begin{array}{l}0.202 * * * \\
(0.067)\end{array}$ & $\begin{array}{l}0.024 \\
(0.079)\end{array}$ & $\begin{array}{l}0.085 \\
(0.083)\end{array}$ \\
\hline Constant & $\begin{array}{l}-0.000 \\
(0.001)\end{array}$ & $\begin{array}{l}0.000 \\
(0.001)\end{array}$ & $\begin{array}{l}-0.072 * * \\
(0.029)\end{array}$ & $\begin{array}{l}4.871 * * * \\
(0.848)\end{array}$ & $\begin{array}{l}5.944 * * * \\
(0.875)\end{array}$ \\
\hline $\mathrm{R}^{2}$ & 0.056 & 0.182 & 0.127 & 0.367 & 0.366 \\
\hline $\mathrm{N}$ & 300 & 300 & 299 & 299 & 299 \\
\hline $\mathrm{FE}$ & --- & YM & --- & YM & YM, WOY \\
\hline
\end{tabular}




\section{Table 3}

\section{ABCP Net Issuance and T-bill Net Issuance}

This table shows regressions of the form

$$
\Delta \ln \left(\text { ABCP OUTSTANDING }_{t}\right)=\alpha+\beta \bullet \Delta \ln \left(\text { T-bills OUTSTANDING } \text { OUT }_{t}\right)+\varepsilon_{t} .
$$

$\ln \left(\mathrm{ABCP} \mathrm{Out}_{t-1}\right)$ is lagged $\log \mathrm{ABCP}$ outstanding, and $\Delta \ln \left(\mathrm{ABCP}\right.$ Out $\left._{t-1}\right)$ is lagged $\log$ net $\mathrm{ABCP}$ issuance (the lagged change in $\log \mathrm{ABCP}$ outstanding), and $\Delta \ln (\mathrm{T}$-bills Out) is $\log$ net Treasury bill issuance. Panel A shows the quantity relationship. In Panel B, we instrument for the T-bill-OIS spread using $\Delta \ln \left(\right.$ T-bills $\mathrm{Out}_{t}$ ). The sample runs weekly from July 2001-June 2007. YM denotes year-month fixed effects, while WOY denotes week-of-year fixed effects. Robust standard errors are reported in parentheses, except for the specifications without fixed effects which report Newey-West standard errors with 12 lags. In specifications with fixed effects, we report the residual $\mathrm{R}^{2} . * * *, * * *$ denote significance at the $10 \%, 5 \%$, and $1 \%$ levels respectively.

\begin{tabular}{lccccc}
\hline \hline & \multicolumn{5}{c}{ Panel A: Quantity Relationships } \\
\cline { 2 - 6 }$\Delta \ln ($ T-bills Out & $-0.035^{* * *}$ & -0.017 & $-0.022^{*}$ & $-0.037^{* * *}$ & $-0.036^{*}$ \\
& $(0.013)$ & $(0.013)$ & $(0.012)$ & $(0.012)$ & $(0.020)$ \\
$\ln ($ ABCP Out & & & $\left.0.006^{* * *}\right)$ & $-0.368^{* * *}$ & $-0.433^{* * *}$ \\
& & & $(0.002)$ & $(0.063)$ & $(0.066)$ \\
$\Delta \ln ($ ABCP Out & & & $\left.0.211^{* * *}\right)$ & 0.027 & 0.080 \\
& & & $(0.067)$ & $(0.079)$ & $(0.083)$ \\
Constant & & & $-0.085^{* * *}$ & $4.985^{* * *}$ & $5.911^{* * *}$ \\
& $0.002^{* * *}$ & $0.002^{* * *}$ & $(0.027)$ & $(0.850)$ & $(0.905)$ \\
\hline $\mathrm{R}^{2}$ & $(0.000)$ & $(0.000)$ & 0.122 & 0.358 & 0.349 \\
$\mathrm{~N}$ & 0.013 & 0.168 & 302 & 302 & 302 \\
$\mathrm{FE}$ & 303 & 303 & --- & $\mathrm{YM}$ & $\mathrm{YM}, \mathrm{WOY}$ \\
\hline \hline
\end{tabular}

\begin{tabular}{|c|c|c|}
\hline \multirow[b]{3}{*}{$\Delta \ln \left(\right.$ T-bills Out $\left.t_{t-1}\right)$} & \multicolumn{2}{|c|}{ Panel B: "IV" Linking Quantities and Spreads } \\
\hline & $1^{\text {st }}$ Stage & $2^{\text {nd }}$ Stage \\
\hline & $\begin{array}{l}1.404 * * * \\
(0.224)\end{array}$ & \\
\hline T-bill - OIS & & $\begin{array}{l}-0.017 * * * \\
(0.006)\end{array}$ \\
\hline $\ln \left(\mathrm{ABCP} \mathrm{Out}_{t-1}\right)$ & & $\begin{array}{l}-0.366 * * * \\
(0.070)\end{array}$ \\
\hline$\Delta \ln \left(\mathrm{ABCP}\right.$ Out $\left._{\mathrm{t}-1}\right)$ & & $\begin{array}{c}0.008 \\
(0.083)\end{array}$ \\
\hline Constant & $\begin{array}{l}0.226^{* * *} \\
(0.004)\end{array}$ & $\begin{array}{l}4.932 * * * \\
(0.939)\end{array}$ \\
\hline $\mathrm{R}^{2}$ & 0.894 & 0.357 \\
\hline $\mathrm{N}$ & 288 & 286 \\
\hline FE & YM & YM \\
\hline
\end{tabular}




\section{Table 4}

\section{ABCP Gross Issuance and T-bill Yields}

This table shows regressions of the form

$$
\ln \left(\text { GROSS ISSUANCE }_{t}\right)=\alpha+\beta \cdot T \text {-bill }- \text { OIS }_{t-1}+\varepsilon_{t} .
$$

T-bill - OIS is the spread of 4-week Treasury bills over the 4-week overnight indexed swap (OIS) rate, $\ln \left(\mathrm{ABCP}\right.$ Out $\left._{\mathrm{t}-1}\right)$ is lagged log ABCP outstanding, and $\ln \left(\right.$ Issuance $\left._{t-1}\right)$ is lagged log gross ABCP issuance. The sample runs weekly from July 2001-June 2007. YM denotes year-month fixed effects. Robust standard errors are reported in parentheses. In specifications with fixed effects, we report the residual $\mathrm{R}^{2}$. $*, * *, * * *$ denote significance at the $10 \%, 5 \%$, and $1 \%$ levels respectively.

\begin{tabular}{|c|c|c|c|c|c|c|}
\hline Maturity(days): & $1-4$ & $5-9$ & $10-20$ & $21-40$ & $41-80$ & $80+$ \\
\hline T-bill - OIS $_{t-1}$ & $\begin{array}{l}-0.353 * * * \\
(0.098)\end{array}$ & $\begin{array}{l}-0.243 \\
(0.180)\end{array}$ & $\begin{array}{l}-0.381 * * \\
(0.149)\end{array}$ & $\begin{array}{l}-0.172 \\
(0.212)\end{array}$ & $\begin{array}{c}0.329 \\
(0.253)\end{array}$ & $\begin{array}{c}0.357 \\
(0.240)\end{array}$ \\
\hline $\ln \left(\right.$ Issuance $\left._{t-1}\right)$ & $\begin{array}{l}-0.034 \\
(0.071)\end{array}$ & $\begin{array}{l}-0.208^{* * *} \\
(0.071)\end{array}$ & $\begin{array}{c}0.053 \\
(0.076)\end{array}$ & $\begin{array}{c}0.013 \\
(0.070)\end{array}$ & $\begin{array}{l}0.340 * * * \\
(0.084)\end{array}$ & $\begin{array}{l}0.191 * * \\
(0.081)\end{array}$ \\
\hline $\ln \left(\mathrm{ABCP}\right.$ Out $\left._{t-1}\right)$ & $\begin{array}{l}-1.806 \\
(1.536)\end{array}$ & $\begin{array}{l}-0.019 \\
(3.331)\end{array}$ & $\begin{array}{l}-2.946 \\
(2.661)\end{array}$ & $\begin{array}{c}3.222 \\
(2.994)\end{array}$ & $\begin{array}{l}-4.558 \\
(3.195)\end{array}$ & $\begin{array}{l}2.026 \\
(3.888)\end{array}$ \\
\hline Constant & $\begin{array}{c}36.189^{*} \\
(20.688)\end{array}$ & $\begin{array}{c}11.276 \\
(44.953)\end{array}$ & $\begin{array}{c}48.402 \\
(36.062)\end{array}$ & $\begin{array}{l}-33.118 \\
(40.450)\end{array}$ & $\begin{array}{c}68.150 \\
(43.168)\end{array}$ & $\begin{array}{l}-19.784 \\
(52.401)\end{array}$ \\
\hline $\mathrm{R}^{2}$ & 0.046 & 0.044 & 0.024 & 0.013 & 0.099 & 0.044 \\
\hline $\mathrm{N}$ & 287 & 287 & 287 & 287 & 287 & 287 \\
\hline FE & $\mathrm{YM}$ & $\mathrm{YM}$ & YM & YM & YM & $\mathrm{YM}$ \\
\hline
\end{tabular}




\section{Table 5}

\section{Reserve Injections and T-bill Yields}

This table shows regressions of the form

$$
\ln \left(\text { RESERVE INJECTION }_{t}\right)=\alpha+\beta \cdot \text { T-bill }-O \mathrm{OIS}_{t-1}+\varepsilon_{t} .
$$

The dependent variable is log reserve injections in week $t$. T-bill - OIS is the spread of 4-week Treasury bills over the 4-week overnight indexed swap (OIS) rate. The sample runs weekly from July 2001-June 2007. The last 3 columns in both panels exclude weeks when the Federal Reserve Open Market Committee meets. In Panel B, the dependent variable is the percentage of reserve injections backed by non-Treasury (i.e. GSE debt and GSE-guaranteed MBS) collateral. YM denotes year-month fixed effects, while WOY denotes week-of-year fixed effects. Robust standard errors are reported in parentheses, except for the specifications without fixed effects which report Newey-West standard errors with 12 lags. In specifications with fixed effects, we report the residual $\mathrm{R}^{2} . * * *, * * *$ denote significance at the $10 \%$, $5 \%$, and $1 \%$ levels respectively.

\begin{tabular}{lclllll}
\hline \hline & \multicolumn{7}{c}{ Panel A: Reserve Injections } \\
\cline { 2 - 7 } T-bill - OIS $_{t-1}$ & $-0.881^{* * *}$ & $-0.538^{* *}$ & $-0.659^{*}$ & $-0.862^{* * *}$ & $-0.563^{* * *}$ & -0.423 \\
& $(0.103)$ & $(0.210)$ & $(0.364)$ & $(0.116)$ & $(0.248)$ & $(0.438)$ \\
Constant & $3.271^{* * *}$ & $3.348^{* * *}$ & $3.020^{* * *}$ & $3.290^{* * *}$ & $3.355^{* * *}$ & $2.969^{* * *}$ \\
& $(0.034)$ & $(0.055)$ & $(0.175)$ & $(0.037)$ & $(0.062)$ & $(0.170)$ \\
\hline $\mathrm{R}^{2}$ & 0.167 & 0.042 & 0.46 & 0.151 & 0.413 & 0.432 \\
$\mathrm{~N}$ & 287 & 287 & 287 & 242 & 242 & 242 \\
$\mathrm{FE}$ & --- & YM & YM, WOY & --- & YM & YM, WOY \\
\hline \hline
\end{tabular}

\begin{tabular}{llllll}
\hline \hline & \multicolumn{5}{c}{ Panel B: Non-Treasury Collateral for Injections } \\
\cline { 2 - 6 } T-bill - OIS $_{t-1}$ & $-0.095^{*}$ & $-0.379^{* * *}$ & $-0.382^{* * *}$ & $-0.295^{* *}$ & $-0.297^{*}$ \\
& $(0.051)$ & $(0.140)$ & $(0.144)$ & $(0.154)$ & $(0.157)$ \\
nonTreasury & & & -0.057 & & -0.059 \\
& & & $(0.079)$ & $(0.080)$ \\
$\ln ($ T-bills Out & & & & -0.700 & -0.711 \\
& & & $(0.530)$ & $(0.536)$ & $(0.530)$ \\
Constant & & & $0.172^{* * *}$ & $4.927^{* * *}$ & 5.062 \\
& $0.227^{* * *}$ & $0.159^{* * *}$ & $(0.035)$ & $(3.682)$ & $(3.644)$ \\
\hline $\mathrm{R}^{2}$ & $(0.015)$ & $(0.033)$ & 0.380 & 0.383 & 0.382 \\
$\mathrm{~N}$ & 0.003 & 0.381 & 287 & 287 & 287 \\
$\mathrm{FE}$ & 287 & 287 & $\mathrm{YM}$ & $\mathrm{YM}$ & $\mathrm{YM}$ \\
\hline \hline
\end{tabular}




\section{Table 6 \\ T-bill Yields and the Federal Funds Rate}

This table shows regressions of the form

$$
\Delta T-\text { bill }-O I S_{t}=\alpha+\beta \cdot \Delta F F T_{t}+\varepsilon_{t} .
$$

T-bill - OIS is the spread of 4-week Treasury bills over the 4-week overnight indexed swap (OIS) rate, FFT is the spread of the Federal Funds rate over its target. All columns except the first and fourth exclude days when the Federal Reserve Open Market Committee meets. The sample runs weekly from July 2001June 2007. YM denotes year-month fixed effects, while WOY denotes week-of-year fixed effects. Robust standard errors are reported in parentheses, except for the specifications without fixed effects which report Newey-West standard errors with 12 lags. In specifications with fixed effects, we report the residual $\mathrm{R}^{2} . * * *, * * *$ denote significance at the $10 \%, 5 \%$, and $1 \%$ levels respectively.

\begin{tabular}{|c|c|c|c|c|c|c|c|}
\hline \multirow[b]{2}{*}{$\Delta \mathrm{FFT}_{t}$} & \multicolumn{3}{|c|}{ Weekly } & \multicolumn{4}{|c|}{ Daily } \\
\hline & $\begin{array}{c}0.031 \\
(0.058)\end{array}$ & $\begin{array}{l}-0.045 \\
(0.075)\end{array}$ & $\begin{array}{l}-0.067 \\
(0.080)\end{array}$ & $\begin{array}{l}-0.171 * * * \\
(0.027)\end{array}$ & $\begin{array}{l}-0.179 * * * \\
(0.028)\end{array}$ & $\begin{array}{l}-0.188^{* * *} \\
(0.029)\end{array}$ & $\begin{array}{l}-0.189 * * * \\
(0.030)\end{array}$ \\
\hline Constant & $\begin{array}{c}0.003 \\
(0.004)\end{array}$ & $\begin{array}{c}0.003 \\
(0.005)\end{array}$ & $\begin{array}{c}0.003 \\
(0.004)\end{array}$ & $\begin{array}{l}0.004^{* * * *} \\
(0.001)\end{array}$ & $\begin{array}{l}0.003 * * \\
(0.001)\end{array}$ & $\begin{array}{l}0.003 * * \\
(0.001)\end{array}$ & $\begin{array}{l}-0.015 \\
(0.029)\end{array}$ \\
\hline $\mathrm{R}^{2}$ & 0.003 & 0.003 & 0.208 & 0.052 & 0.051 & 0.038 & 0.076 \\
\hline $\mathrm{N}$ & 287 & 242 & 242 & 1061 & 988 & 988 & 988 \\
\hline $\mathrm{FE}$ & --- & --- & $\mathrm{YM}$ & --- & --- & YM & YM, WOY \\
\hline
\end{tabular}




\section{Table 7}

\section{Aggregate Monetary Quantities and T-bill Yields}

This table shows regressions of the form

$$
\ln \left(M_{t}\right)=\alpha+\beta \cdot T-b i l l-O I S_{t}+\varepsilon_{t}
$$

where $\mathrm{M}_{\mathrm{t}}$ is some measure of aggregate money in week $t$. T-bill - OIS is the spread of 4-week Treasury bills over the 4-week overnight indexed swap (OIS) rate. The sample runs weekly from July 2001-June 2007, except for the last column, which runs monthly over the same period. Robust standard errors are reported in parentheses. YM denotes year-month fixed effects, while YQ denotes year-quarter fixed effects. In specifications with fixed effects, we report the residual $\mathrm{R}^{2} . *{ }^{* *}, * * *$ denote significance at the $10 \%, 5 \%$, and $1 \%$ levels respectively.

\begin{tabular}{|c|c|c|c|c|c|c|}
\hline & Reserves & Deposits & $\begin{array}{c}\text { MMMF } \\
\text { Retail }\end{array}$ & $\begin{array}{c}\text { MMMF } \\
\text { Institutional } \\
\end{array}$ & M2 & Fedwire \\
\hline T-bill - OIS t-1 $_{1}$ & $\begin{array}{l}-0.071 * * * \\
(0.015)\end{array}$ & $\begin{array}{l}-0.003 \\
(0.003)\end{array}$ & $\begin{array}{l}-0.005 \\
(0.005)\end{array}$ & $\begin{array}{l}-0.008 \\
(0.009)\end{array}$ & $\begin{array}{l}-0.005^{* *} \\
(0.002)\end{array}$ & $\begin{array}{l}-0.086^{* * * *} \\
(0.024)\end{array}$ \\
\hline Constant & $\begin{array}{l}10.662 * * * \\
(0.004)\end{array}$ & $\begin{array}{c}15.432 * * * \\
(0.001)\end{array}$ & $\begin{array}{c}6.660 * * * \\
(0.001)\end{array}$ & $\begin{array}{l}7.091 * * * \\
(0.002)\end{array}$ & $\begin{array}{c}8.746^{* * *} \\
(0.001)\end{array}$ & $\begin{array}{l}14.466^{* * * *} \\
(0.006)\end{array}$ \\
\hline $\mathrm{R}^{2}$ & 0.072 & 0.002 & 0.007 & 0.004 & 0.033 & 0.190 \\
\hline $\mathrm{N}$ & 287 & 287 & 287 & 287 & 287 & 66 \\
\hline $\mathrm{FE}$ & YM & YM & YM & YM & YM & YQ \\
\hline
\end{tabular}




\section{Table 8}

\section{Response of Other Issuers}

This table shows regressions of the form

$$
\text { Issuer_Response } e_{t}=\alpha+\beta \cdot T \text {-bill-OIS }{ }_{t-1}+\varepsilon_{t} \text {. }
$$

In Panel A, Issuer Response is the aggregate net (long minus short) position of the primary dealers in a given security type. In Panel B, Issuer Response is net $\log$ issuance of unsecured commercial paper. T-bill - OIS is the spread of 4-week Treasury bills over the 4-week overnight indexed swap (OIS) rate, and $\ln \left(\mathrm{T}-\right.$ bills Out $\left._{t-1}\right)$ is lagged log Treasury bills outstanding. The sample runs weekly from July $2001-J u n e ~ 2007$. Robust standard errors are reported in parentheses. In specifications with month fixed effects, we report the residual $\mathrm{R}^{2} . *, * *, * * *$ denote significance at the $10 \%, 5 \%$, and $1 \%$ levels respectively.

\begin{tabular}{|c|c|c|c|c|c|c|}
\hline \multirow[b]{3}{*}{ T-bill - OIS ${ }_{t-1}$} & \multicolumn{6}{|c|}{ Panel A: Primary Dealers } \\
\hline & \multicolumn{2}{|c|}{ T-bills } & \multirow{2}{*}{$\begin{array}{l}\text { All Treasuries } \\
64461 * * * \\
(16165)\end{array}$} & \multirow{2}{*}{$\begin{array}{l}\text { GSE Debt } \\
8442 \\
(5840)\end{array}$} & \multirow{2}{*}{\begin{tabular}{l}
\multicolumn{1}{c}{ MBS } \\
$-18934^{* * *}$ \\
$(5882)$
\end{tabular}} & \multirow{2}{*}{\begin{tabular}{l}
\multicolumn{1}{c}{ Corp } \\
$-17995^{* * *}$ \\
$(5128)$
\end{tabular}} \\
\hline & $\begin{array}{l}71286^{* * *} \\
(10483)\end{array}$ & $\begin{array}{l}68144 * * * \\
(11957)\end{array}$ & & & & \\
\hline BAA Spread $_{t-1}$ & $\begin{array}{l}25984 \\
(17582)\end{array}$ & $\begin{array}{l}27290 \\
(17378)\end{array}$ & $\begin{array}{l}79595 * * * \\
(25879)\end{array}$ & $\begin{array}{l}-15581 \\
(11058)\end{array}$ & $\begin{array}{l}-5052 \\
(15919)\end{array}$ & $\begin{array}{l}-19416 \\
(12076)\end{array}$ \\
\hline Yield Spread $_{t-1}$ & $\begin{array}{l}20880 * * * \\
(6943)\end{array}$ & $\begin{array}{l}21430 * * * \\
(7045)\end{array}$ & $\begin{array}{l}9024 \\
(9365)\end{array}$ & $\begin{array}{l}-6653^{*} \\
(3548)\end{array}$ & $\begin{array}{l}-12902 * * * \\
(4517)\end{array}$ & $\begin{array}{l}-9249 * * * \\
(3472)\end{array}$ \\
\hline $\ln \left(\mathrm{T}\right.$-bills Out $\left.\mathrm{O}_{\mathrm{t}-1}\right)$ & & $\begin{array}{l}30630 \\
(48270)\end{array}$ & $\begin{array}{l}33579 \\
(60319)\end{array}$ & $\begin{array}{l}5824 \\
(17501)\end{array}$ & $\begin{array}{l}-15589 \\
(25919)\end{array}$ & $\begin{array}{l}56902 * * * \\
(21430)\end{array}$ \\
\hline Constant & $\begin{array}{l}-67894 * \\
(36107)\end{array}$ & $\begin{array}{l}-281819 \\
(336007)\end{array}$ & $\begin{array}{l}-461667 \\
(419636)\end{array}$ & $\begin{array}{l}91944 \\
(124050)\end{array}$ & $\begin{array}{l}168721 \\
(187614)\end{array}$ & $\begin{array}{l}-195095 \\
(150215)\end{array}$ \\
\hline $\mathrm{R}^{2}$ & 0.471 & 0.472 & 0.439 & 0.490 & 0.436 & 0.499 \\
\hline $\mathrm{N}$ & 287 & 287 & 287 & 287 & 287 & 287 \\
\hline FE & YM & YM & YM & YM & YM & YM \\
\hline
\end{tabular}




\begin{tabular}{lllll}
\hline & \multicolumn{3}{c}{ Panel B: Unsecured Commercial Paper Issuers } \\
\cline { 2 - 5 } T-bill - OIS $\mathrm{t}-1$ & $-0.007^{* *}$ & $-0.016^{*}$ & $-0.009^{*}$ & -0.006 \\
& $(0.003)$ & $(0.009)$ & $(0.005)$ & $(0.008)$ \\
$\ln \left(\right.$ CP Out $\left._{\mathrm{t}-1}\right)$ & & & -0.014 & 0.100 \\
& & & $(0.072)$ & $(0.066)$ \\
$\Delta \ln \left(\mathrm{CP} \mathrm{Out}_{\mathrm{t}-1}\right)$ & & & -0.005 & $-0.725^{* * *}$ \\
& & & $(0.009)$ & $(0.084)$ \\
Constant & -0.001 & -0.002 & 0.066 & $9.800^{* * *}$ \\
& $(0.001)$ & $(0.002)$ & $(0.125)$ & $(1.139)$ \\
\hline $\mathrm{R}^{2}$ & 0.011 & -0.056 & 0.006 & 0.316 \\
$\mathrm{~N}$ & 287 & 287 & 286 & 286 \\
$\mathrm{FE}$ & & $\mathrm{YM}$ & & $\mathrm{YM}$ \\
\hline \hline
\end{tabular}

